\title{
Trends in Interdisciplinary Studies Revealing Porphyrinic Compounds Multivalency Towards Biomedical Application
}

\author{
Radu Socoteanu ${ }^{1}$ et al. ${ }^{*}$ \\ IIlie Murgulescu Institute of Physical Chemistry, Romanian Academy, \\ Romania
}

\section{Introduction}

Porphyrins are a unique class of compounds widely present in nature. Due to their distinct chemical and photophysical properties they have a variety of applications, the most important being presented in Fig. 1.

Porphyrin chemistry and their applications have undergone a renaissance in the last years reflected in the 20 volumes of the recent comprehensive work giving an overview of the field (Kadish K.M et al., 2002). Despite the impressive volume of data, the question about the actual trends and future involvement of porphyrins in biomedical applications is still a hot topic as reflected by the number of publications on photodynamic therapy (Fig.2).

In the last decades a great deal of efforts from the scientific community focused on developing new therapeutic and diagnosis approaches in major diseases, like cancer and infection. One of the most dynamic fields of investigation is photodynamic therapy (PDT), which takes advantage of controlled oxidative stress for destroying pathogens.

This article aims at reviewing major topics related to biomedical engineering, porphyrins for PDT and photodiagnosis (PDD). We do not intend to provide an exhaustive display and comment of the porphyrinoid structures, as a huge number on papers and reviews dealing with the subject have already been published. We emphasize herein that porphyrins are also among the most promising candidates to be used as fluorescent near infrared (NIR) probes for non-invasive diagnosis and this opens the possibility to perform simultaneously tumor imaging and treatment in the same approach. It is worth mentioning that, besides their medical applications, porphyrins are used in industrial and analytical applications as

\footnotetext{
${ }^{*}$ Rica Boscencu2 ${ }^{2}$, Anca Hirtopeanu ${ }^{3}$, Gina Manda ${ }^{4}$, Anabela Sousa Oliveira ${ }^{5,6}$, Mihaela Ilie ${ }^{2}$ and Luis Filipe Vieira Ferreira ${ }^{6}$.

1 Ilie Murgulescu Institute of Physical Chemistry, Romanian Academy, Romania,

2 Carol Davila University of Medicine and Pharmacy, Faculty of Pharmacy, Romania,

3 Costin Nenitescu Institute of Organic Chemistry, Romanian Academy, Romania,

4 Victor Babes National Institute, Romania,

5 Centro Interdisciplinar de Investigação e Inovação, Escola Superior de Tecnologia e Gestão,

Instituto Politécnico de Portalegre, Portugal,

6 Centro de Química-Física Molecular, Institute of Nanosciences and Nanotechnology,

Instituto Superior Técnico, Portugal.
} 
sensitized solar cells, pigments, in electrocatalysis, as electrodes in fuel cells, and as chemical sensors, but these issues are not the subject of this paper. Therefore the present chapter will only address the medical applications of porphyrins and metalloporphyrins with a special emphasis on photodynamic therapy.

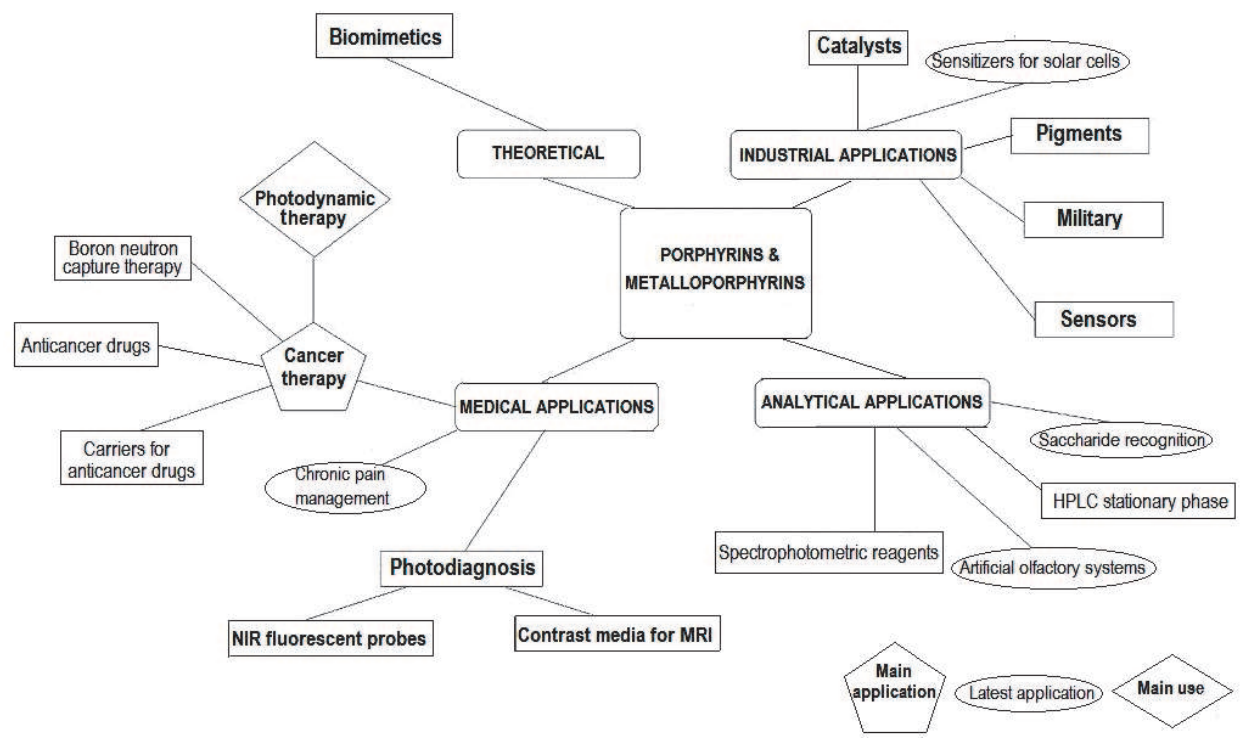

Fig. 1. Applications of porphyrins and metalloporphyrins

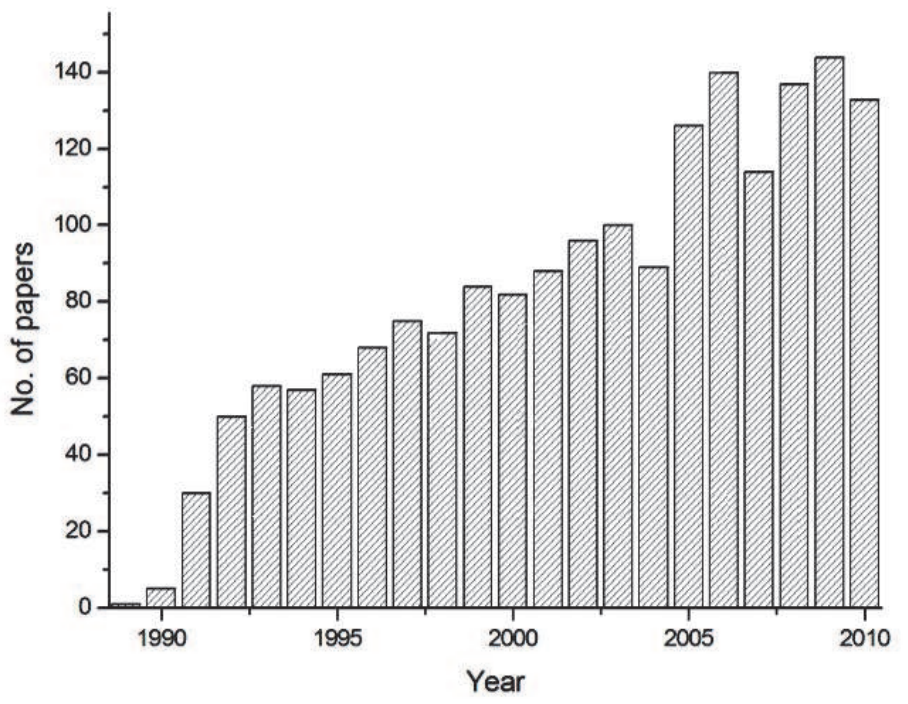

Fig. 2. Ascendant trend of publications on the topic of porphyrins involved in photodynamic therapy, as indexed by ISI Web of Knowledge 
We summarize herein basic concepts in the field, stressing out theoretical and technological limitations that currently restrict multidisciplinary research for improving /enlarging theoretical and technological approaches in PDT and PDD using porphyrins. Special emphasis will be given to the development of novel porphyrinic structures related or derived from already confirmed structures and to put them in connection with PDT and PDD applications, focusing on symmetrical vs. asymmetrical molecular structures and on classical vs. more recent synthetic methods. Dosimetry issues for controlling and characterizing related processes, interdisciplinary approaches (chemistry, physics, biochemistry and biomedicine) will be also highlighted.

The major role played by porphyrinoid systems in biomedical applications is due to their photochemical (energy and exciton transfer), redox (electron transfer, catalysis) and coordination properties (metal and axial ligand binding) and their conformational flexibility (functional control) (Senge et al., 2010). The issue of PDT will be extensively adressed in the next section, while other medical applications, some of them very recent, will be described in section 4 .

\section{Photodynamic therapy - main medical application of porphyrins}

PDT typically combines a photosensitizer, molecular oxygen and light to destroy cancer cells and microorganisms by oxidative stress (Bonnett R., 2000). Briefly, PDT is based on the ability of photosensitisers, including porphyrins, to selectively accumulate and kill tumour cells (Dougherty, 1987) by singlet oxygen $\left({ }^{1} \mathrm{O}_{2}\right)$ (Berenbaum \& Bonnett, 1990), upon guided light activation with a particular wavelength (usually via laser endoscopy). Reactive oxygen species (ROS) produced by phagocytes underly physiological defense mechanisms against microorganisms, which are highly controlled to destroy pathogens, whilst minimally affecting the surrounding healthy tissues (Witko-Sarsat et al., 2000). As reviewed by Manda et al. (2009) cancer cells show an intrinsic oxidative phenotype, which makes them more sensitive to the deleterious action of additional oxidative stress generated for therapeutical purposes either by radiotherapy, PDT or even chemotherapy.

PDT has gained increasing attention in the past decade as a targeted and less invasive treatment regimen for a number of medical conditions, spanning from various types of cancers and dysplasias to neoangiogenesis, macular degeneration, as well as bacterial infections. The advantage is that PDT provides a localized action rather than a systemic one, when compared to other cancer therapies which are more harmful to the patient. PDT for cancer treatment has been extensively reviewed (Allison \& Sibata, 2010; Capella M.A.M. \& Capella L.S., 2003; Dickson, 2003; Dolmans, 2003; Dougherty, 1998; O'Connor et al., 2009; Vrouenraets, 2003; Wilson B.C., 2002). The huge effort in PDT development is highlighted by 1074 papers in the field reviewed in PubMed in the last 2 years, while 72 clinical trials in PDT were ongoing in March 2011 (http:/ / clinicaltrials.gov).

\subsection{Mechanism of action}

As summarized in Fig. 3, there are two recognized mechanisms of action for PDT. The first mechanism (type I) involves light induced excitation of the photosensitizer, promoting an electron to a higher energy state. At this point a variety of reactions can take place. For example, the photosensitizer in the excited state can act as a reducing agent in the reaction to create ROS. Conversely, the excited photosensitizer may act as an oxidizing agent by filling the hole vacated by the excited electron. The second mechanism (type II) also 
involves excitation of the photosensitizer with light, but energy is transferred in this case to the triplet ground state of molecular oxygen, resulting in excited singlet state oxygen which is highly cytotoxic (Otsu K et al., 2005). In type I mechanism, oxygen is not always necessary for the photodynamic action to take place; however, in type II mechanism, oxygen is essential. Differences in the triplet and singlet states reflect ways in which two eectrons can be placed in degenerate orbitals and, as such, provide an ideal system to examine processes that give rise to Hund's rules for orbital occupancy. Also, the near IR transition between the 8 triplet and singlet states, at $1270 \mathrm{~nm}$, is not very probable and provides an excellent example of selection rules based on changes in spin and orbital angular momentum, symmetry, and parity.

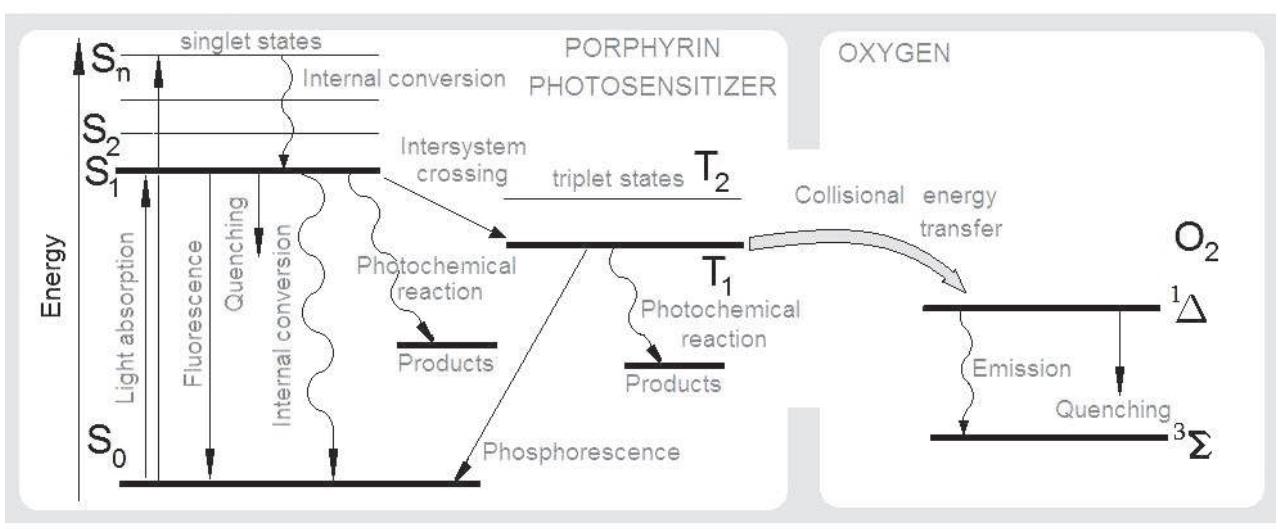

Fig. 3. Photophysical processes involving porphyrinic sensitizer in the presence of oxygen in a modified Jablonski diagram

The photophysical processes required for photodynamic therapy evidentiate the relevant properties for the photosensitizer: wavelength of absorbed light, molar absorbance, fluorescent quantum yield, intersystem crossing quantum yield, singlet oxygen quantum yield and photobleaching quantum yield. These properties depend on the chemical structure of the photosensitizer and will be discussed in paragraph 3.1.

\subsection{PDT, ROS and targeted cell death}

A prominent feature of PDT relies in focusing light and consequent localized photoactivation of the sensitizer. This spares normal tissue from the deleterious action of ROS generated during PDT reactions. Moreover, selective accumulation of sensitizer in tumors was demonstrated, which relies in physiological differences between tumors and normal tissues; among them can be cited: tumors have a larger interstitial volume than normal tissues, often contain a larger fraction of phagocytes, contain a large amount of newly synthesized collagen, have a leaky microvasculature and poor lymphatic drainage. Additionally, the extracellular $\mathrm{pH}$ is low in tumors. Generally cationic sensitizers localize in both the nucleus and mitochondria, lipophilic ones tend to stick to membrane structures, and water-soluble drugs are often found in lysosomes. Not only the lipid/water partition coefficient is important but also other factors such as molecular weight and charge distribution (linked to symmetry/asymmetry of the photosensitizer structure). In some 
cases, light exposure leads to a relocalization of the sensitizers (Moan \& Berg, 1992; Moan \& Peng, 2003; Spikes, 1989).

Singlet oxygen is a highly reactive ROS that interacts with proteins, nucleic acids and lipids. Singlet oxygen has a short lifetime within the cell and can migrate in tissues less than $20 \mathrm{~nm}$ after its formation. Therefore, the induced injury by singlet oxygen action is highly localized. Nevertheless, generation of about $9 \times 10^{8}$ molecules of singlet oxygen per tumor cell significantly reduces the cell surviving fraction (Dysart et al., 2005).

PDT leads to a molecular interplay between cell death pathways, balancing between apoptosis, necrosis and autophagy (Dewaele et al., 2010). Generally, photosensitizers which specifically target mitochondria induce ROS-mediated cell death by apoptosis (Oleinick et al., 2002), while autophagy occurs during PDT protocols involving sensitizers that localize to the endoplasmic reticulum (ER) (Buytaert, 2006; Kessel, 2006). Nonetheless, Pavani et al. (2009) demonstrated that photodynamic efficiency is directly proportional to membrane binding and is not totally related to mitochondrial accumulation. The presence of zinc in the photosensitizer decreases mitochondrial binding and increases membrane interactions, leading to improved PDT efficiency.

Recent evidence points out that mitochondria and ER associated with B-cell lymphoma 2 are among the cellular targets damaged in PDT protocols, impacting both apoptosis and autophagy. Autophagy may function as a prosurvival or a death pathway in PDT. The former function is obvious at low-dose PDT conditions, whereas the latter one contributes to the killing of cells exhibiting a phenotype that precludes the development of an apoptotic response, or of those cells that surviving to the initial wave of apoptosis after high-dose PDT (Kessel 2007; Pattingree, 2005). Apoptosis dominates as a mechanism of cell death in those cells having a fully competent apoptotic machinery, whereas autophagy seems to be responsible for cell death when apoptosis is compromised (Xue et al., 2007).

ROS are biologically multifaceted molecules, despite their simple chemical structure. Depending on the magnitude and profile of ROS generation in biological systems, on cellular location and on the redox balance, ROS can elicit cell death or cell proliferation. On one hand, aerobic organisms adapted themselves to the injurious oxidative attack and even learned how to use ROS in their own favor, as signaling molecules. On the other hand, ROS proved to be powerful weapons in fighting against infection or as therapeutic armentarium exploiting oxidative stress. Radiotherapy is one of the clearest examples of anti-cancer treatment, whose mechanism relies primarily on ROS, combining the properties of an extremely efficient DNA-damaging agent with high spatial focusing on tumor. Radiotherapy limitation derives mainly from the carcinogenic potential of the ionizing radiation and from the deleterious side-effect associated with the inflammatory response triggered by necrosis. Radiation memory underlies long-lasting effects of radiotherapy in tumors, but also contributes to persistent damage and dysfunctions of bystander normal cells. Taking also advantage of ROS cytotoxic potential, but with significantly less sideeffects than radiotherapy, PDT is a fascinating example of biomedical engineering, combining and targeting towards diseased tisssues a photosensitizer, light and oxygen. It is an interdisciplinary approach involving chemistry, physics, biology and medicine for synergizing and fine-tuning all the three above mentioned components towards an efficient and highly targeted treatment regimen.

Although other classes of molecules have been tested and used as photosensitizers, porphyrins and porphyrin-like structures are undoubtly the most relevant for biomedical applications. Porphyrins and porphyrin-like structures have long been of interest for PDT 
due to their low intrinsic toxicity, the ability to accumulate into tumors and to generate highly ROS only when photoactivated at convenient wavelengths, adequate for deep tissue penetration.

\subsection{PDT in oncology}

It is now obvious that PDT can work as well as surgery or radiation therapy in treating certain kinds of cancers and dysplasias, having clear advantages over these treatment approaches: no long-term side effects when properly used, less invasive than surgery, can be targeted more precisely, can be repeated many times at the same site, if needed, and finally it is often less expensive than other cancer treatments.

The evidence in the published peer-reviewed scientific literature (Awan, 2006; Fayter, 2010; Rees, 2010) supports PDT as a safe and effective treatment option for selected patients with Barrett's esophagus, esophageal cancer, and non-small cell lung cancer. Although PDT has been proposed for the treatment of various other types of cancers (e.g., head and neck, cholangiocarcinoma, prostate), there is still insufficient evidence in the form of welldesigned large, randomized controlled trials. PDT is also successful in the treatment of actinic keratoses, Bowen's disease and basal cell carcinoma.

PDT limitations are mainly related to drug and light accessibility. Although the photosensitizer travels throughout the body, PDT only works at the area exposed to light. This is why PDT cannot be used to treat leukemias and metastasis. Also, PDT leaves patients very sensitive to light, therefore special precautions must be taken after photosensitizers are used. PDT cannot be used in people who have acute intermittent porphyria or people who are allergic to porphyrins.

More aggressive local therapies are often necessary to eradicate unresectable tumor cells that invade adjacent normal tissue (i.e., malignant glioma), and this might be achieved by combining PDT and boron neutron capture therapy (BNCT) (Barth et al., 2005). Both are bimodal therapies, the individual components being non-toxic, but tumoricidal in combination. Boronated porphyrins are promising dual sensitizers for both PDT and BNCT, showing tumor affinity by the porphyrin ring, ease of synthesis with a high boron content, low cytotoxicity in dark conditions, strong light absorption in the visible and NIR regions, ability to generate singlet oxygen upon light activation and also ability to display fluorescence (Vicente et al., 2010). Several boronated porphyrins have been synthesized and evaluated in cellular and animal studies (Renner, 2006; Vicente, 2010).

Besides more precise photosensitizer targeting, either by specific cellular function-sensitive linkages or via conjugation to macromolecules (Verma S. et al., 2007), recent approaches aim to combine PDT and a second treatment regimen to either increase the susceptibility of tumor cells to PDT or to mitigate molecular responses triggered by PDT. As an example, Anand et al. (2009) demonstrated both in vitro and in vivo that low, non-toxic doses of methotrexate can significantly and selectively enhance PDT with aminolevulinic acid in skin cancers. Banerjee et al (2001) showed that meso-substituted porphyrins could impact directly in the radiotherapy outcome, when labeled with beta(-) emitters like 186/188Re.

\subsection{PDT and immunomodulation}

In contrast with systemic chemo- or radiotherapy, PDT is a local treatment in which the treated tumor remains in situ, while the immune response is only locally affected and has the capability to recover by recruitment of circulating immune cells. 
Generally, immune cells are found in the tumor stroma, separated from tumor cells by extracellular matrix and basal membrane-like structures which hinder the development of an efficient anti-tumor immune response. By destroying the structure of the tumor, PDT facilitates direct interaction between immune and tumor cells, resulting in a local or systemic immune response, as shown in both preclinical as well as clinical settings (Gollnick, 2002). Nonetheless, the efficiency of the in situ vaccination triggered by PDT is still debatable (van Duijnhoven et al., 2003).

As reviewed by Garg et al (2010), PDT is capable of eliciting various effects in the tumor microenvironment thereby affecting tumor-associated immune cells and the activation of different immune reactions e.g. acute-phase response, complement cascade and production of cytokines/chemokines (Garg et al., 2010). The ability of PDT to induce exposure/release of certain damage-associated molecular patterns (DAMPs) like HSP70, opens new perspectives in PDT and PDT-like photoimmunotherapy (Garg et al., 2010).

PDT, by evoking oxidative stress at specific subcellular sites through light-activation of organelle-associated photosensitizers, may be unique in combining tumor cells destruction and antitumor immune response in one therapeutic paradigm (Garg et al., 2011).

\subsection{Antimicrobial PDT}

The very success of antibiotics limited their efficiency by rendering microorganisms resistant (Hancock R.E.W., 2007). PDT seems to be a viable alternative, proving to be efficient against bacteria (including drug-resistant strains), yeasts, viruses and protozoa. In addition to destroying microorganisms, PDT can induce immune stimulatory reactions (Castano et al., 2006; Hryhorenko et al., 1998), and consequently has the potential to improve the overall host response to infections.

The positive charge of photosensitizers appears to promote a tight electrostatic interaction with negatively charged sites at the outer surface of any species of bacterial cells (Maisch et al., 2004). Moreover, drug-resistant microorganisms are as susceptible to PDT as their native counterparts (Maisch, 2009), or even more susceptible (Tang et al., 2009). It is considered less likely that the bacteria will develop resistance towards PDT (Jori \& Coppellotti, 2007; Konopka \& Goslinski, 2008), presumably because of the short-lived ROS produced by the photodynamic effect and the non-specific nature of the photooxidative damage that leads to cell death.

It is known that gram-positive bacteria species are much more sensitive to photodynamic inactivation than gram-negative species (Merchat et al., 1996). Efforts have therefore been made to design photosensitizers capable of attacking gram-negative strains. This can be achieved if photosensitizers are coadministrated with outer membrane disrupting agents such as calcium chloride, EDTA or polymixin B nonapeptide, that are able to promote electrostatic repulsion and consequent alteration of the cell wall structure.

As reviewed by Alves et al. (2009), porphyrins can be transformed into cationic entities through the insertion of positively charged substituents in the peripheral positions of the tetrapyrrole macrocycle, which affect the kinetics and extent of binding to microorganisms. The hydrophobicity of porphyrins can be modulated by the number of cationic moieties (up to four in meso-substituted porphyrins) or by the introduction of hydrocarbon chains of different length on the amino nitrogens.

Antimicrobial PDT is making rapid advances towards clinical applications in oral infections, periodontal diseases, healing of infected wounds and treatment of Acne vulgaris. The first product to be applied in the oral cavity came on the market in Canada in 2005 (Periowave $^{\mathrm{TM}}$, 
Ondine) and several products for the treatment of infected wounds are under clinical trial. Antimicrobial PDT requires topical applications of the photosensitizers, selective for the microorganism, without causing significant damage to the host tissue. The possibility of adverse effects on host tissues has often been raised as a limitation of antimicrobial PDT. However, studies have shown that the photosensitizers are more toxic against microbial species than against mammalian cells, and that the concentration of photosensitizer and light energy dose necessary to kill the infecting organism has little effect on adjacent host tissues.

Photoactivated disinfection of blood samples and surfaces like benches and floors is also introduced as a promising application of antimicrobial PDT. The group of Parsons (2009) developed a method for concentrating PDT effect at a material surface to prevent bacterial colonization by attaching a porphyrin photosensitizer at, or near to that surface. Anionic hydrogel copolymers were shown to permanently bind a cationic porphyrin through electrostatic interactions as a thin surface layer. The mechanical and thermal properties of the materials showed that the porphyrin acts as a surface cross-linking agent, and renders surfaces more hydrophilic. Importantly, Staphylococcus epidermidis adherence was reduced by up to $99 \%$ relative to the control in intense light conditions and $92 \%$ in the dark. As such, candidate anti-infective hydrogel-based intraocular lens materials were developed for improving patient outcomes in cataract surgery.

\section{Porphyrins as PDT photosensitizers}

Porphyrins are involved as sensitizers in PDT because of their ability to localize in tumors and of their capacity to be activated by irradiation (see Fig 3).

The main basic architectures of the porphyrinoid compounds used as photosensitizers are presented in Fig. 4 highlighting the minor differences between them. Porphyrins and porphyrin-related dyes used in PDT may have substituents in the peripheral positions of the pyrrole rings or on the four methine carbons (meso-positions).

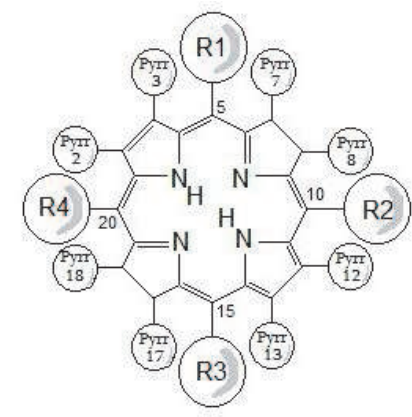

Dihydroporphyrin

(Bacteriochlorin)

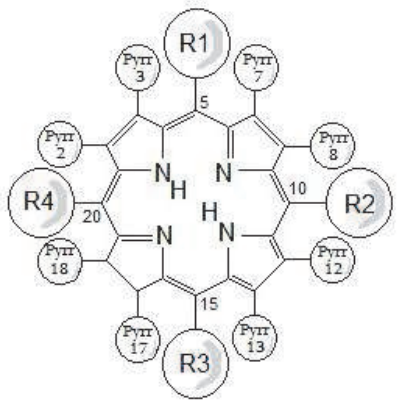

Tetrahydroporphyrin

(Chlorin)

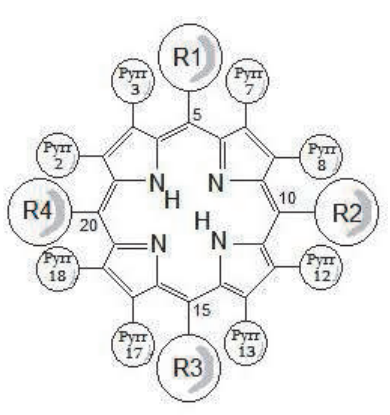

Porphyrin

Fig. 4. Basic architectures of porphyrinoid photosensitizers

These derivatives are synthesized to influence the water/lipid solubility, amphiphilicity, $\mathrm{pKa}$ and stability of the compounds since these parameters determine their pharmacokinetics. 
Porphyrins can also coordinate metal ions by replacing the hydrogen atoms on nitrogen; the metal ion and its electronic properties are of importance for their photocytotoxic potential as photosensitisers. Several metallophotosensitizers have been developed for clinical purposes. Although in most cases, they have lower quantum yields for cell inactivation than they would have in the absence of metal ions, they have other properties like improved solubility and stability, which makes them interesting as therapeutic substances. The metals used include $\mathrm{Zn}, \mathrm{Pd}, \mathrm{Sn}, \mathrm{Ru}, \mathrm{Pt}$ and $\mathrm{Al}$.

\subsection{Properties of porphyrins relevant for their biomedical applications}

The use of porphyrins in biomedical applications including PDT is tightly connected to their physical - chemical characteristics. Among these, most important are their electronic molecular absorption and emission properties, but solubility and stability must also be taken into account.

\subsubsection{Absorption properties}

Porphyrinoids have a large range of absorption wavelengths together with a large range of molar absorbtion coefficients as shown in Fig. 5. Although the absorption of porphyrins does not cover the entire PDT window, they compensate that with their ability to localize in tumors and their chemical versatility.
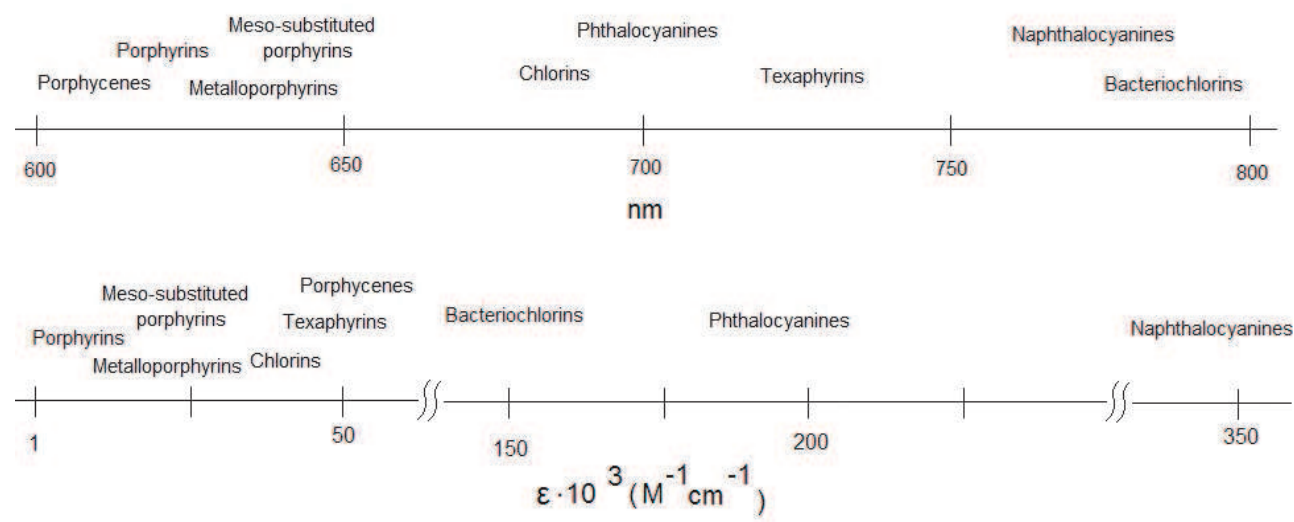

Fig. 5. Chart of one exclusive pair criteria for photosensitizers suitable for PDT: absorption maxima vs. intensity $(\varepsilon)$

The electronic absorption spectrum of the free-base porphyrins is dominated by a typical intense Soret band and four weaker $Q$ bands, located in the spectral range 415-650 nm, which are monotonously decreasing in intensity (Kadish et al., 2002). The $Q$ bands of the free base porphyrins consist of four absorption peaks which are typical to the $Q x(0,0)$, $\mathrm{Qx}(0,1), \mathrm{Qy}(0,0), \mathrm{Qy}(0,1)$ transitions in the free base porphyrin $\left(\mathrm{D}_{2 \mathrm{~h}}\right.$ symmetry). Upon complexation with a metal ion, the number of $Q$ bands decreases due to the enhancement of the molecular symmetry from $\mathrm{D}_{2 \mathrm{~h}}$ to $\mathrm{D}_{4 \mathrm{~h}}$ (Boscencu et al., 2008; Boscencu et al., 2010). The molecular electronic absorption spectra are usually used for the quantitative determination of compounds, but in the case of porphyrinic compounds they give real "fingerprints" that 
can be used to predict the usefulness of a certain compound as photosensitizer. This is explained by the fact that the peripheral substitution does not significantly disturb the inner $\Pi$ electron ring of the porphyrinic macrocycle, which is responsible for the active electronic transitions in the above mentioned spectral range.

\subsubsection{Emission properties}

Photodetection for tissue characterization in cancer is not new, the first study being reported by Policard in 1924, who noticed the fluorescence of a tumor under illumination with UV light. This fluorescence was considered to originates from tumor's endogenous porphyrins (Masilamani et al., 2004). Some of the most important aspects of metaloporphyrins are connected to the photophysical characteristics of porphyrins in different media: fluorescence quantum yields $\left(\Phi_{\mathrm{f}}\right)$ and fluorescence lifetimes $\left(\tau_{\mathrm{f}}\right)$.

Fluorescence emission characteristics of porphyrinic compounds are also important features for the biomedical use of porphyrins. In case of their use in photodiagnosis, emission characteristics as fluorescence quantum yields and/or fluorescence lifetimes are of importance to differentiate the signal of the fluorescent marker from the fluorescence of the environmental matter. In case of PDT, all deactivation processes (fluorescence, phosphorescence, internal conversion, collisional quenching) play an important role in the very process of ROS generation (Fig. 3).

Despite significant advantages, the porphyrinic compounds as photosensitizers have limitations. Due to the large $\pi$ conjugate systems, they easily form aggregates, which have a significantly lower ability to form reactive oxygen species and consequently decrease the photodynamic activity. In recent years, nanostructured materials such as liposomes, nanoparticles and micelles have been considered as potential carriers for porphyrinic compounds that may resolve the aforementioned problems. The presence of polar headgroups and hydrophobic chains in micellar structures allows the study of the potential affinity of a porphyrinic structure to cell-membrane type structures.

\subsection{Main features for an efficient photosensitizer}

There is a great deal of interest in design and synthesis of new photosenzitizers with porphyrinoid structures, with improved characteristics that make worth their investigation as possible new PDT drugs. The general characteristics of a good sensitizer, displayed as basic requirements, are presented in Table 1. For photosensitizers designed to kill cancer or other mammalian cells, it has been found that their intracellular localization is another important parameter. For example, the photosensitizers which localize in mitochondria seem to be more powerful in killing cells than those locating in lysosomes (Mroz et al., 2009).

Porphyrins are essential constituents of important biological systems. The porphyrin-type nucleus, along with metal ions, is found in cytochromes, peroxidases and catalases. Other biologically important porphyrins that occur in nature and in the human body are hemin (an iron porphyrin - the prosthetic group of hemoglobin and myoglobin), chlorophyll (magnesium porphyrin-like compound involved in plant photosynthesis), and vitamin B12 (cobalt porphyrin-like compound, commonly known as cobalamine). As a result of their vital role in biologic processes, metallo-porphyrins have always attracted chemist's attention. Porphyrins proved to be valuable photosensitizers since they are non-toxic, are selectively retained in tumors, are cleared in a reasonable time from the body and skin, and thus photosensitive reactions are minimized. Moreover, porphyrins have got convenient 
amphiphilicity which renders them more photodynamically active than symmetrically hydrophobic or hydrophilic molecules.

\begin{tabular}{|c|c|}
\hline Required features & Details \\
\hline Purity & $\begin{array}{l}\text { Substance of known composition, stable at room } \\
\text { temperature }\end{array}$ \\
\hline $\begin{array}{c}\text { Toxicity, overdosage, and side } \\
\text { effects }\end{array}$ & $\begin{array}{l}\text { - Minimal toxicity in the absence of light } \\
\text { - Cytotoxic in the presence of light of defined } \\
\text { wavelength } \\
\text { - Non- toxic metabolites; } \\
\text { - Minimal side effects }\end{array}$ \\
\hline $\begin{array}{c}\text { Absorption, distribution, } \\
\text { metabolism and excretion (ADME) }\end{array}$ & Optimum ADME properties \\
\hline Activation and wavelength & $\begin{array}{l}\text { Activation in the phototherapeutical window (600 to } \\
850 \mathrm{~nm})\end{array}$ \\
\hline $\begin{array}{l}\text { Singlet oxygen } \\
\text { quantum yield }\end{array}$ & High singlet oxygen generation quantum yield $(\Phi \Delta)$ \\
\hline Cost and availability & $\begin{array}{l}\text { Inexpensive } \\
\text { Commercially available to allow extensive utilization }\end{array}$ \\
\hline Selectivity & $\begin{array}{l}\text { - Good tumour/healthy tissue localization ratio } \\
\text { - Favourable subcellular localization to induce an } \\
\text { apoptotic rather than a necrotic mode of cell death }\end{array}$ \\
\hline $\begin{array}{l}\text { Mutagenicity/ } \\
\text { Carcinogenicity }\end{array}$ & $\begin{array}{l}\text { Non-mutagenic } \\
\text { Non-carcinogenic }\end{array}$ \\
\hline Painless & $\begin{array}{l}\text { No pain during the procedure or in the following } \\
\text { treatment stages }\end{array}$ \\
\hline Combined treatment & $\begin{array}{l}\text { No adverse interactions with other drugs or medical } \\
\text { procedures }\end{array}$ \\
\hline Multisession & $\begin{array}{l}\text { Possibility for application in repeated sessions, } \\
\text { without immunosuppressive effects }\end{array}$ \\
\hline Carriers & Possibile formulation with different carriers \\
\hline $\begin{array}{l}\text { Multivalency } \\
\text { Marker } \\
\text { and molecular beacon }\end{array}$ & $\begin{array}{l}\text { Multiple effects desired (antitumoral and } \\
\text { antimicrobial, antitumor and diagnosis) } \\
\text { Marker or beacon }\end{array}$ \\
\hline Upgradable chemical structures & $\begin{array}{l}\text { The structure can be easily improved by simple } \\
\text { chemical reactions }\end{array}$ \\
\hline
\end{tabular}

Table 1. Required features for an efficient photosensitizer

\subsection{Timeline in the development of porphyrinoid photosensitizers}

Porphyrins were identified in the mid-nineteenth century, but it was not until the early twentieth century that they were used in medicine. 


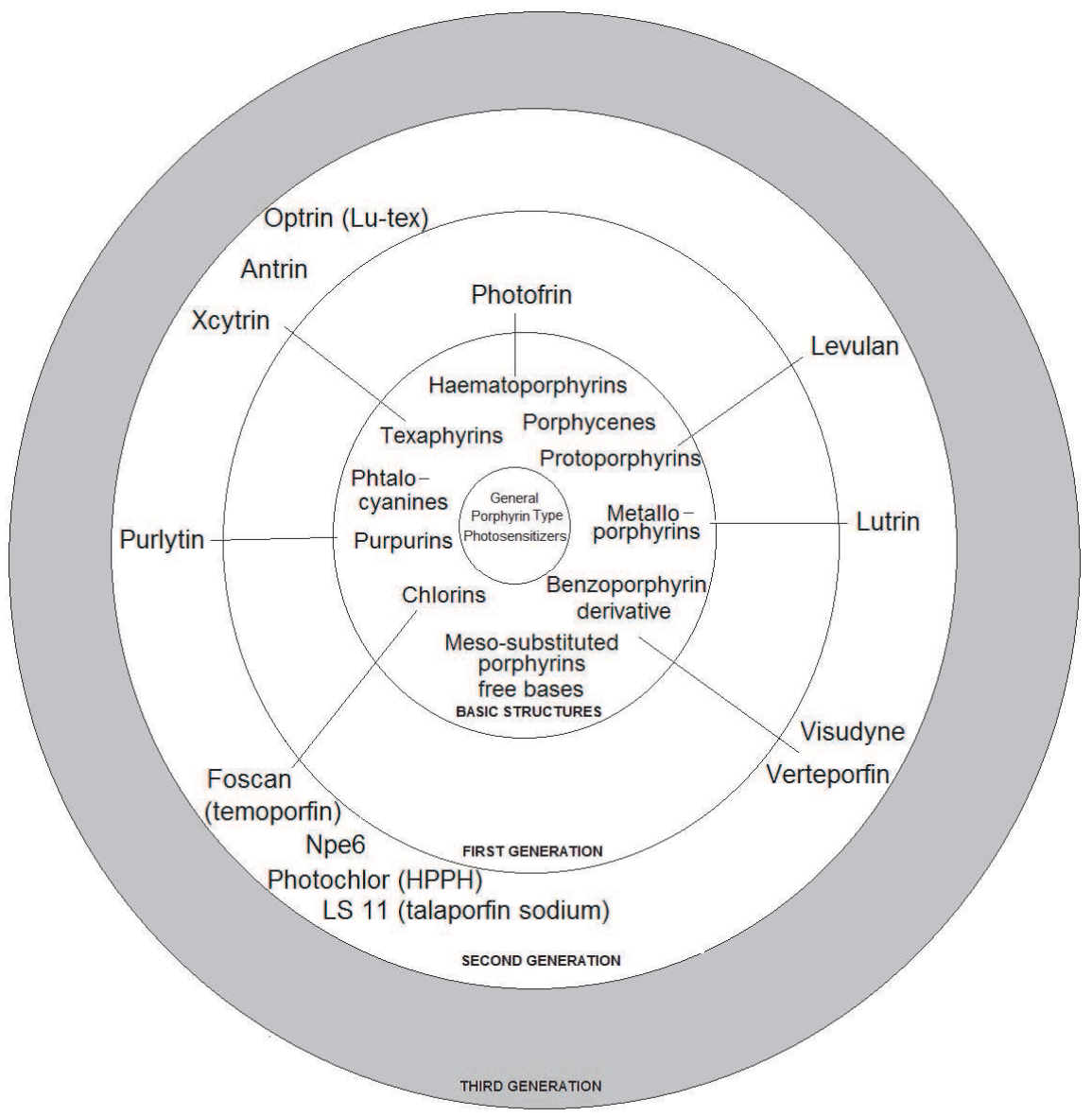

Fig. 6. General frame of the porphyrin type structures involved in biomedical studies

Porphyrinoid photosensitizers are classified as belonging to the first, second or third generation of photosensitizers as shown in Figure 6, or depending on the platform to which they belong (porphyrin, chlorophyll, dyes) (Allison R.R. et al., 2004). They could also be classified according to their primary mechanism of action and/or according to their use (type of cancer, photodiagnosis or therapy).

The first generation of photosensitizers consists only of hematoporphyrin derivatives and was developed during the 70 's. Photosensitizers belonging to the second generation are porphyrin derivatives or synthetics made from the late ' 80 s on. Second generation 10 photosensitizers are improved compared to the first generation: they have a definite structure (which means they are no more a combination of monomers, dimers and oligomers), absorb light at longer wavelengths and cause less skin photosensitization.

Third generation photosensitizers use available drugs and then modify them with different carriers in order to obtain tailored characteristics.

Examples of clinically available porphyrin sensitizers are presented in Table 2. 
Trends in Interdisciplinary Studies Revealing

\begin{tabular}{|c|c|c|c|c|c|}
\hline Brand names & Substance (structure) & $\begin{array}{c}\text { Substance } \\
\text { Name } \\
\text { (abbreviation) } \\
\end{array}$ & $\begin{array}{c}\text { Substance chemical } \\
\text { name }\end{array}$ & \begin{tabular}{|c|} 
Activation \\
wavelengt \\
h $(\mathbf{n m})$
\end{tabular} & Manufacturer \\
\hline Photofrin & & $\mathrm{HpD}$ & Hematoporphyrin & 630 & $\begin{array}{c}\text { Axcan Pharma, } \\
\text { Inc. }\end{array}$ \\
\hline Levulan & & ALA & $\begin{array}{l}\text { 5-Aminolevulinic } \\
\text { acid }\end{array}$ & 630 & \begin{tabular}{|c|} 
DUSA \\
Pharmaceuticals \\
Inc.
\end{tabular} \\
\hline $\begin{array}{l}\text { Metvix } \\
\text { Metvixia }\end{array}$ & & M-ALA & $\begin{array}{c}\text { Methyl-5- } \\
\text { Aminolevulinic acid }\end{array}$ & 634 & \begin{tabular}{|c|} 
PhotoCure ASA \\
Galderma, \\
Dallas, TX \\
\end{tabular} \\
\hline Visudyne & & Verteporfin & & 690 & $\begin{array}{c}\text { Novartis } \\
\text { Pharmaceuticals }\end{array}$ \\
\hline Foscan & & Temoporfin & $\begin{array}{c}\text { 5,10,15,20-tetrakis (3- } \\
\text { hydroxyphenyl)- } \\
\text { chlorin }\end{array}$ & 652 & $\begin{array}{l}\text { Biolitec Pharma } \\
\text { Ltd. }\end{array}$ \\
\hline $\begin{array}{c}\text { LS11 } \\
\text { NPe6 } \\
\text { Laserphyrin }\end{array}$ & & Talaporfin & $\begin{array}{l}\text { mono-L-aspartyl } \\
\text { chlorine e6 }\end{array}$ & 664 & Light Science \\
\hline Photochlor & & HPPH & $\begin{array}{c}\text { 2-(1-Hexyloxyethyl) } \\
\text {-2-devinyl } \\
\text { pyropheophorbide-a }\end{array}$ & 665 & RPCI \\
\hline
\end{tabular}

Table 2. Clinically available porphyrin sensitizers (adapted from Allison et al., 2004) 
Photofrin ${ }^{\circledR}(\mathrm{HpD})$ has the longest clinical history and patient track record being the first commercial photosensitiser. It is actually a combination of monomers, dimers, and oligomers derived from chemical manipulation of hematoporphyrin $(\mathrm{HpD})$. The complex mixture is required for clinical activity. In the US, Photofrin ${ }^{\circledR}$ is FDA approved for early and late endobronchial lesions as well as Barrett's esophagus and esophageal obstructing lesions. The drug is approved worldwide for a number of additional uses, such as for treatment of bladder cancer.

5-Aminolevulinic acid (ALA) is a prodrug, a naturally occurring amino acid which is converted enzymatically to protoporphyrin. By topical administration the treatment can be selectively performed without associated light sensitization of the untreated regions. Systemic administration does not have this built in selectivity. The drug is active at $630 \mathrm{~nm}$, which should give adequate depth penetration; however, when topically administered, the drug has a limited penetration capacity and therefore is less efficient for treating deep

\begin{tabular}{|c|c|c|c|}
\hline \multirow[b]{2}{*}{$\begin{array}{l}\text { Porphyrin } \\
\text { sensitizer } \\
\text { molecular } \\
\text { structure }\end{array}$} & $\begin{array}{l}\text { First generation } \\
\text { photosensitizers }\end{array}$ & \multicolumn{2}{|c|}{ Second generation photosensitizers } \\
\hline & & & \\
\hline \begin{tabular}{|c|} 
Porphyrin \\
sensitizer name
\end{tabular} & Photofrin & Tookad & Foscan \\
\hline $\begin{array}{l}\text { Absorption } \\
\text { (nm) }\end{array}$ & 630 & 763 & 652 \\
\hline Localization & $\begin{array}{l}\text { Golgi apparatus } \\
\text { plasma membrane }\end{array}$ & Vasculature & $\begin{array}{c}\text { Endoplasmic reticulum } \\
\text { (ER) } \\
\text { Mitochondria }\end{array}$ \\
\hline $\begin{array}{l}\text { Primary } \\
\text { mechanism of } \\
\text { action }\end{array}$ & $\begin{array}{l}\text { Vascular damage } \\
\text { ischemic tumor cell necrosis }\end{array}$ & $\begin{array}{l}\text { Vascular damage } \\
\text { Direct tumor cytotoxicity }\end{array}$ & Vascular damage \\
\hline $\begin{array}{c}\text { Most commonly } \\
\text { light time } \\
\text { irradiation } \\
\text { interval }\end{array}$ & $24-48 \mathrm{~h}$ & $15 \mathrm{~min}$ & $96 \mathrm{~h}$ \\
\hline Status: & Approved & Clinical trials & Approved \\
\hline Applications & $\begin{array}{c}\text { Esophageal cancer, lung } \\
\text { cancer, gastric cancer, cervical } \\
\text { dysplasia and cancer }\end{array}$ & Prostate cancer & Head and Neck cancer \\
\hline $\begin{array}{l}\text { Local side } \\
\text { effects }\end{array}$ & Mild to moderate erythema & - & $\begin{array}{l}\text { Swelling, bleeding, } \\
\text { ulceration scarring }\end{array}$ \\
\hline $\begin{array}{l}\text { Systemic side } \\
\text { effects }\end{array}$ & $\begin{array}{l}\text { Photosensitivity, mild } \\
\text { constipation }\end{array}$ & - & - \\
\hline
\end{tabular}

Table 3. Examples of porphyrin sensitizers and their characteristics (adapted from O'Connor et al., 2009) 
lesions. ALA is not highly active, so relatively high light doses or long time treatments are needed. Despite using topical anesthetics, ALA PDT can be painful. ALA has been successful for esophageal treatment and with the oral form of drug this is convenient. Dysplastic epithelium can be reliably destroyed by ALA PDT.

The methylated form of ALA (M-ALA), known commercially as Metvix® in Europe and Metvixia ${ }^{\circledR}$ in the US, has FDA approval for the treatment of non-hyperkeratotic actinic keratoses of the face and scalp, using a red-light source. Metvix also has EU approval for the treatment of superficial basal cell carcinomas. Both ALA and its methylated form proved clinical efficacy in the treatment of actinic keratoses and have also been used for photorejuvenation and inflammatory acne vulgaris.

Verteporfin, known commercially as Visudyne, is a benzoporphyrin derivative, which is clinically active when formulated with liposomes. The photosensitizer is active at $690 \mathrm{~nm}$, allowing deep tissue penetration and light activation. The drug is rapidly accumulated and cleared, so that skin photosensitization is minimal. Most of the clinical response induced by Verteporfin is based on vascular disruption and therefore, this drug seems ideal for lesions depending on neovasculature.Verteporfin has been successful as treatment for choroidal neovascularization due to serous chorioretinopathy.

Table 3 presents some of the clinically available sensitizers together with their most relevant features in order to emphasize the influence of the chemical changes (among others, free base versus metallated form) on the characteristics and applications.

\subsection{Selected aspects of the synthesis}

Synthesis of porphyrins has been extensively reviewed in literature (Kadish K., 2002).

The hematoporphyrin derivatives $(\mathrm{HpD})$ were the start line for the porphyrinic photosensitizers, the result consisting in several commercial products, as Photofrin ${ }^{\circledR}$, which is a mixture of oligomers formed by ether and ester linkages of several porphyrin units, delivered as sodium porphimer. Their efficacy is linked also to the different proportions of monomers, dimers and oligomers (Mironov et al., 1990). The porphyrinic ring is $\beta$-pyrrolic substituted in this case. By changing the substitution on the meso positions, new photosensitizers can be generated, such as the tetraphenylsulphonated structures (TSPP or TSPP4-meso-tetrakis(4-sulfonatophenyl)porphyrin). Despite a few advantages, as solubility and low cost, the neurotoxicity, cytoskeletal abnormalities and nerve fiber degeneration in systemic administration, has oriented the compound only to topical use (Lapes M. et al., 1996; Winkelman J.W. et al., 1987).

Meso-substituted porphyrins (Fig. 7) are more attractive compared to the naturally occurring beta substituted porphyrins for different applications including the biomedical field. Their synthesis is an ongoing subject of research (Halime Z. et al., 2006; Senge M.O., 2010, 2005; Lindsey J.S. 2010) being directed toward increasing efficacy in obtaining unsymmetric ABCD substituted structures, in larger quantities. One approach is the use of microwave (MW) irradiation which offers excellent yields within minutes.

As shown in figure 7, the porphyrin ring can be substituted in its 5, 10, 15 and 20 positions respectively with $R_{1}, R_{2}, R_{3}$ and $R_{4}$. If the substituents are all hydrogen atoms, the structure is a symmetrical porphin; if the substituents are not hydrogens, but are identical to each other, the structure is a symmetrical meso porphyrin. Whenever one or more of $R_{1}$ to $R_{4}$ is not hydrogen, the structure is an unsymmetrical porphyrin. Porphyrins are said to have type A unsymmetrical structure when only $R_{1}$ is not hydrogen; type $A, B-5,10$ or type $A, B-5,15$ when either $R_{1}$ and $R_{2}$ or $R_{1}$ and $R_{3}$ are not hydrogens; type $A B C$ if only $R_{4}$ is 
hydrogen and type ABDC when none of the substituents is hydrogen. Whenever unsymmetrical, porphyrins posses an amphiphilic character.
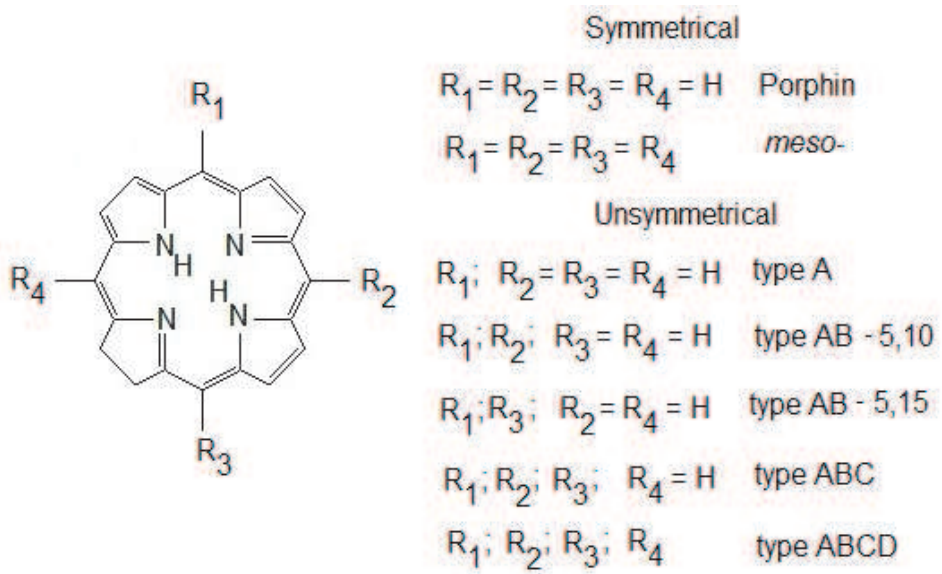

Fig. 7. Substitution patterns for porphyrins

The quest for viable structures, able to compete with Foscan (also known as Temoporfin, see Table 2), has included as spearhead the meso- substituted amphiphilic porphyrins. The desirable hydrophilic configurations give short singlet oxygen lifetime, unsuitable to PDT (Bonnett R., 2000). Controlled equilibrium in terms of hydrophilic-hydrophobic character was obtained in structures where porphyrinic periphery was mainly achieved by synthesizing a large number of asymmetrical structures, with all $R_{x}(1$ to 4$)$ different (i.e., an ABCD unsymmetrical structure) (Rao et al., 2000; Wiehe et al., 2005). For increased targeted delivery and enhancement of phototoxicity by raising the level of the accumulation in pathologic cells, several carboplatin-containing porphyrins were synthesized (Brunner et al., 2004).

New structures were synthesized by several methods. The conjugation approach, coupled with photophysical studies and biological evaluation was reported for several compounds, from folic acid (Schneider et al., 2005) to Pt(II)-containing structures (Song et al., 2002).

The posibility to add functional groups to the substituted porphyrin recommends this type of compounds for multiple biomedical purposes.

\subsubsection{Classical synthesis}

Since the 20's, with the work of Nobel laureates H.Fischer and R. Willstätter on porphyrins as haemoglobin, chlorophyll and other pigments, followed later by R.B Woodward and A. Eschenmoser with the synthesis of vitamin B12, considered at the time as impossible, porphyrin synthesis has been continuously leading to complex structures. The Rothemund process is considered as classical (Rothemund, 1936, 1939) with the contributions of Adler Longo (Longo, 1969; Adler, 1976) and those of Lindsey (Lindsey, 1986, 1987).

Some of the complex porphyrinic structures were obtained by adding various substituents in all peripheral positions (Fig. 4), others by expanding the core- beginning with five pyrrole units: sapphyrin (Chmielewski et al., 1995) and smaragdyirin (Sessler et al., 1998) to the turcasarin (Sessler et al., 1994) as relevant extreme examples. 
The general synthetic methods for meso-porphyrins are presented in Figure 8.

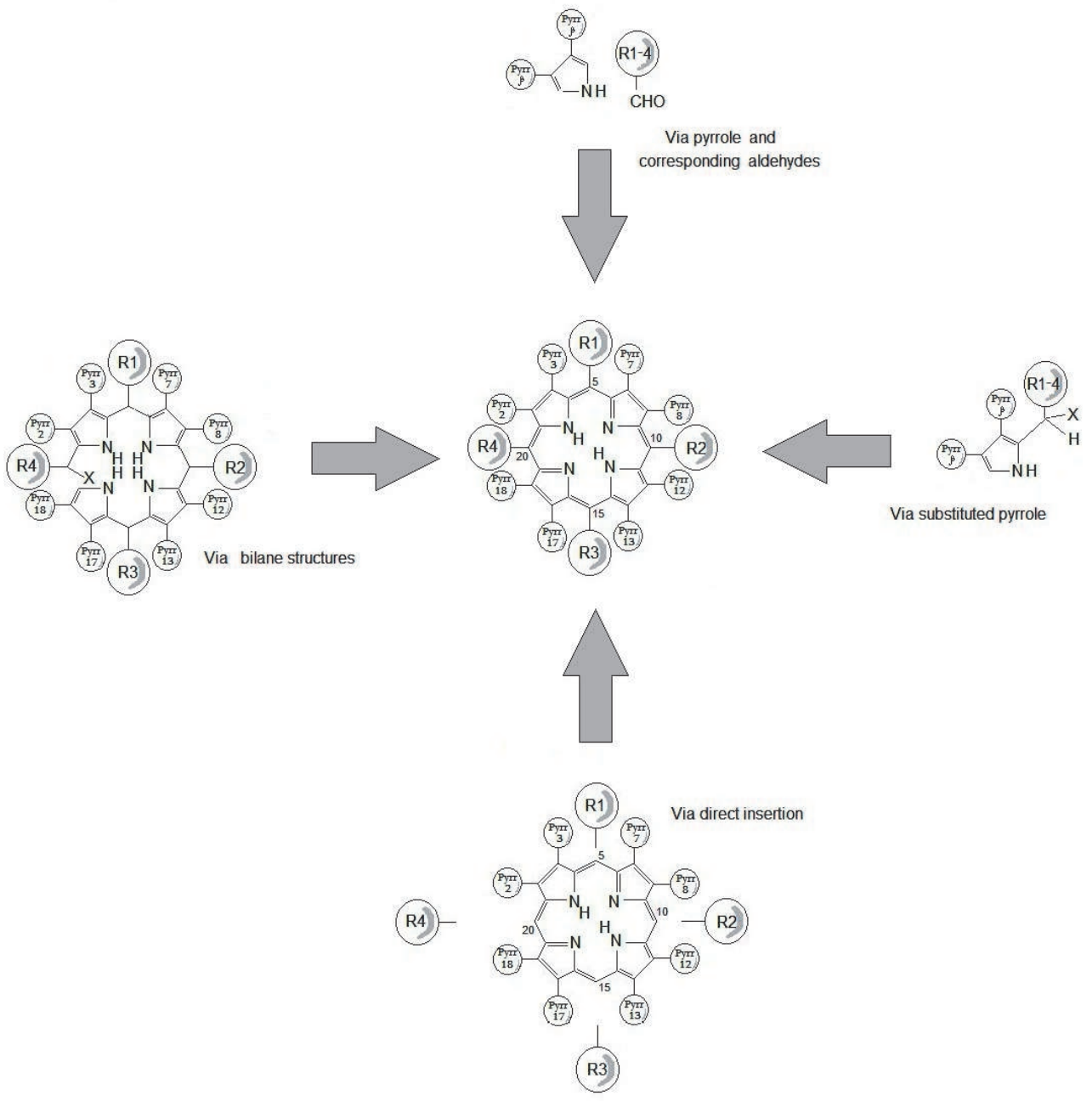

Fig. 8. Theoretical synthetic approach for the peripheral substitution on meso- porphyrins

Four pathways are generally available (according to Fig. 8): the condensation process involving pyrrole and various aldehydes, reaction mixture involved also in MW assisted procedures, the combination of substituted pyrroles carrying the desired future porphyrin substituents or via bilane structure; this last option was successfully applied on ABCD substituted porphyrins via synthesis of a protected acylbilane (by acid-catalyzed condensation of a acyldipyrromethane and protected dipyrromethane-n-carbinol) (Dogutan et al., 2007) and insertion of the substituents in meso positions in the already formed porphyrin core.

The unsymmetrical porphyrins were chosen as our main synthetic target (Boscencu, 2008, 2009, 2010; Oliveira, 2009) because 
a. they are easy to prepare either via the Adler route (Adler et al., 1976) or by microvawe (MW) irradiation

b. the phenolic hydroxy group is a suitable site on which to build a different substituent (Milgrom LR, 1983)

c. the 4-methoxycarbonyl side-chains of the other meso-substituents may be de-esterified to convert a hydrophobic porphyrin into a hydrophilic one.

\subsubsection{Synthesis by microwave irradiation}

Microwave-assisted procedure is now a valid method to synthesize various type of compounds, including porphyrins and related structures, with significant advantages, from eco-friendliness to fastness and selectivity (Loupi et al., 2001). Since the first successful attempt for the meso-5,10,15,20 tetraphenylporphyrin (Petit et al., 1992), a wide range of compounds were obtained using either professional or domestic microwave ovens. The metalloporphyrins can also be obtained via MW methods (Mark et al., 2005).

Microwave-assisted procedures have become increasingly important in chemical synthesis in the last two decades due to several already proved important advantages over conventional heating pathways (table 4).

The position of the microwave irradiation stage in preliminary evaluation-synthetic processpurification- analysis chain is just by replacing classical Rothemund method with no additional operations (Fig. 9.)

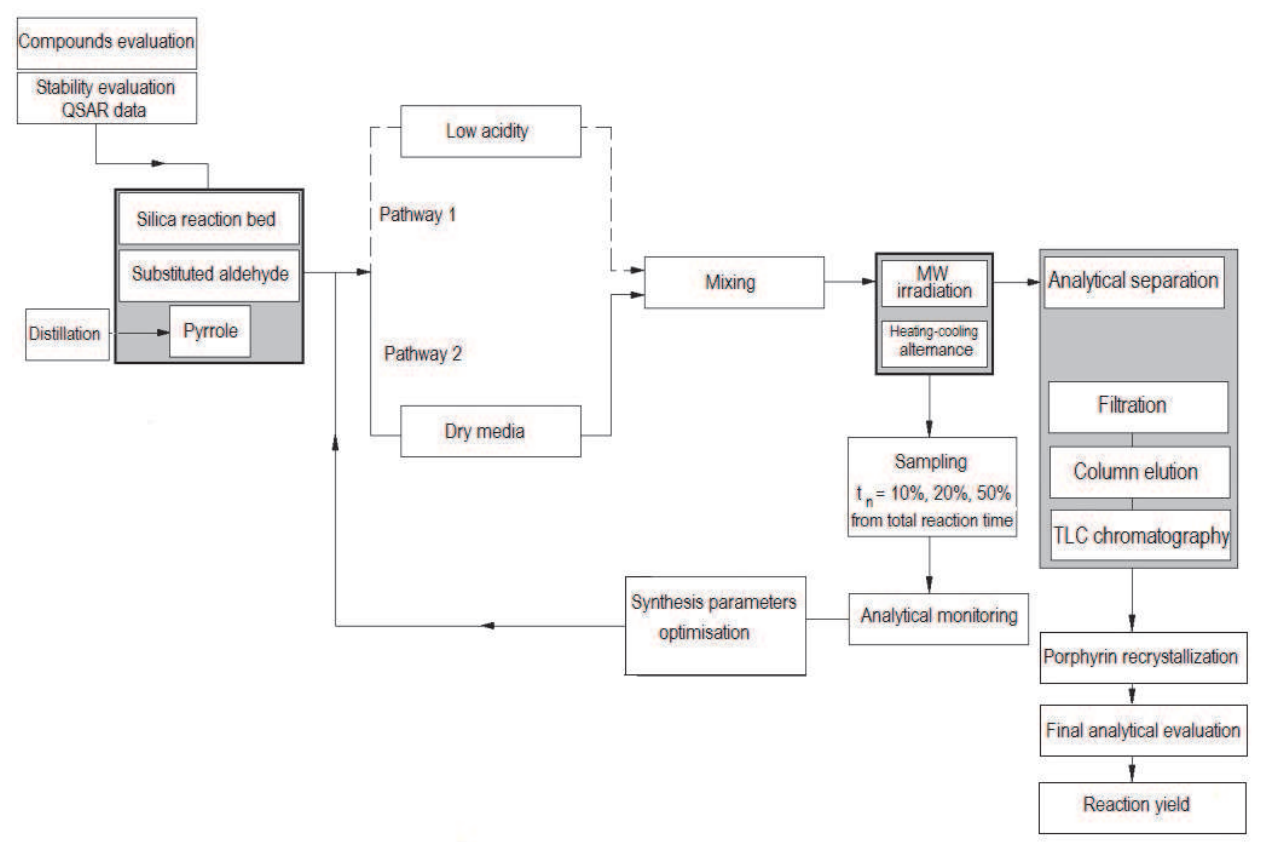

Fig. 9. Synthesis strategy for obtaining porphyrinic compounds including both classical and MW irradiation methods 
The microwave-assisted cyclocondensation of benzaldehyde and pyrrole in dry media or in propionic acid (Chauhan et al., 2001) produces 5,10,15,20-tetraaryl porphyrins type with excellent yields.

\begin{tabular}{|c|c|c|}
\hline Characteristics & Classical Method & MW Method \\
\hline $\begin{array}{c}\text { Reaction environment } \\
\text { (starting materials) }\end{array}$ & $\begin{array}{c}\text { Complex } \\
\text { (reactants in greater number) }\end{array}$ & Simple \\
\hline Conditions & $\begin{array}{c}\text { Difficult } \\
\text { (pressure, temperature, Nitrogen } \\
\text { atmosphere) }\end{array}$ & Easy \\
\hline Experimental & $\begin{array}{c}\text { Precautions } \\
\text { (adding reagents under special } \\
\text { conditions) }\end{array}$ & No restrictions \\
\hline Reaction yield & $\begin{array}{c}\text { Small-Average } \\
\text { Time }\end{array}$ & Average-High \\
\hline Toxicity & Average & Minutes \\
\hline $\begin{array}{c}\text { Secondary } \\
\text { reaction products }\end{array}$ & $\begin{array}{c}\text { High } \\
\text { (separation in several steps) }\end{array}$ & Fverage-Low \\
\hline $\begin{array}{c}\text { Chlorine } \\
\text { (related structure) }\end{array}$ & Present & Absent \\
\hline
\end{tabular}

Table 4. Characteristics of the MW vs. classical synthetic method

The pathway towards improved photosensitizers imposed extended interdisciplinary studies. The second generation of photosensitizers will provide a large volume of "starting material" for future clinical tests, considering that the present synthetic methods can provide almost all types of substituted porphyrinoid systems.

\section{Other medical applications of porphyrins}

Porphyrins and metalloporphyrins have applications in cancer therapy, in photodiagnosis and more recently in chronic pain management and in the emerging field called theranostics which is actually a combination between therapy and diagnosis (Ray et al., 2010).

\subsection{Cancer therapy}

\subsubsection{Boron neutron capture therapy}

Boron neutron capture therapy (BNCT) is a binary radiation therapy approach, bringing together two components which, when kept separate, have only minor effects on cells. The first component is a stable isotope of boron (boron-10) that can be concentrated in tumor cells by attaching it to tumor-seeking compounds. The second is a beam of low-energy neutrons. Boron-10 into or adjacent to the tumor cells disintegrates after capturing a neutron producing high energy heavy charged particles which destroy only the cells in close proximity, primarily cancer cells, leaving adjacent normal cells largely unaffected. Clinical interest in BNCT has focused primarily on the treatment of high-grade gliomas and either cutaneous primaries or cerebral metastases of melanoma, most recently, head, neck and 
liver cancer. Neutron sources for BNCT are limited to nuclear reactors and these are available in the US, Japan, several European countries, and Argentina (Bregadze et al., 2001; Evstigneeva et al., 2003; Fronczek et al., 2005; Ol'shevskaya et al., 2006; Vicente et al., 2003). Boron-containing porphyrins have excellent tumor-localizing properties (Vicente, 2001) and have been proposed for dual application as boron delivery agents and photosensitizers for PDT in brain tumors (Rosenthal, 2003).

\subsubsection{Anticancer drugs}

A series of interesting gold(III) meso-tetraarylporphyrin complexes with relevant antiproliferative effects on CNE1 human cancer cell lines were described by Che et al. (2003). Among them, the complex $\mathrm{Au}(\mathrm{III})(p-\mathrm{H}-\mathrm{TPP})] \mathrm{Cl}$ was found to be more cytotoxic for CNE1 than cisplatin. The lack of cross-resistance suggested that gold(III) porphyrins and cisplatin induced cytotoxicity through different mechanisms. Replacement of $\mathrm{Au}(\mathrm{III})$ with $\mathrm{Zn}(\mathrm{II})$ drastically reduced the drug potency.

Cationic Mn porphyrins may be advantageous compared to other anti-cancer drugs, owing to their ability to afford pain management in cancer patients (Rabbani et al., 2009).

\subsubsection{Carriers for anti-cancer drugs}

The tumor-affinity of porphyrins has been exploited for designing porphyrin-anticancer drug conjugates. Brunner et al. created a series of porphyrin-platinum conjugates by combining porphyrin with cytotoxic platinum complexes (Brunner, 2004; Lottner, 2002). Zhou reported some porphyrin - DNA-alkylation-agent conjugates (Zhou, 2006) and Guo et al. $(2003,2004)$ prepared conjugates by linking porphyrin with other nitrogen heterocyclic species. However none of the conjugates mentioned above may be considered as a prodrug, since they do not release the actual drug. The first example of a porphyrin anticancer prodrug was reported in 2008 and consists of three parts: a porphyrin, a photocleavable $o$ nitrobenzyl moiety as a light-triggered group, and a parent anticancer drug Tegafur (Lin et al., 2008). The prodrug is significantly less toxic than its parent anticancer drug Tegafur, which is released upon photoactivation.

Combined with the up-to-date medical fiber optic technique, the light-triggered porphyrin anticancer prodrugs may find useful applications in chemotherapy to minimize side effects of anticancer drugs and in the light-controllable anticancer drug dosing (McCoy et al., 2007).

\subsection{Chronic pain management}

Severe pain syndromes reduce the quality of life of patients with inflammatory and neoplastic diseases, partly because reduced analgesic effectiveness of chronic opiate therapy leads to escalating doses and distressing side effects. Peroxynitrite $\left(\mathrm{ONOO}^{-}\right)$and its reactive oxygen precursor superoxide $\left(\mathrm{O}_{2}{ }^{\cdot-}\right)$, are critically important in the development of pain.

Metalloporphyrins have the highest rate constants for scavenging $\mathrm{O}_{2}{ }^{-}$and $\mathrm{ONOO}-$ and were shown to alleviate conditions originating from oxidative stress, such as diabetes, cancer, radiation injury, and central nervous system injuries, including morphine antinociceptive tolerance (Salvemini \& Neuman, 2010, Salvemini et al., 2011). The most potent ONOO- scavengers and superoxide dismutase mimics reported so far are cationic Mn(III) N-alkylpyridylporphyrins (Fig. 10) (Batinić-Haberle et al, 1999; Rebouças et al., 2008a; Rebouças et al., 2008b). 


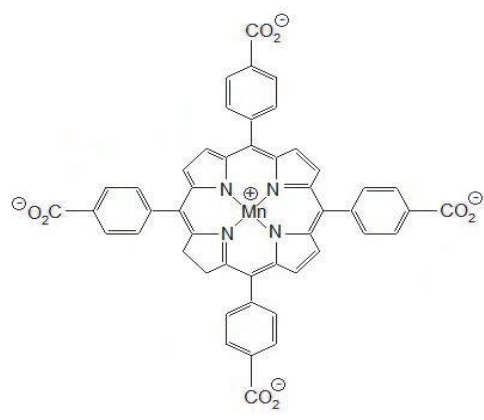

MnTBAP

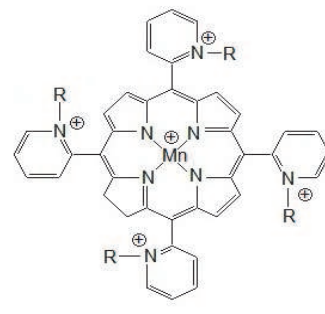

$\operatorname{MnTE}-2-\mathrm{PyP}^{5+}(\mathrm{R}=\mathrm{Et})$ MnTnHex-2-Py ${ }^{5+}(\mathrm{R}=\mathrm{nH}$ ex $)$

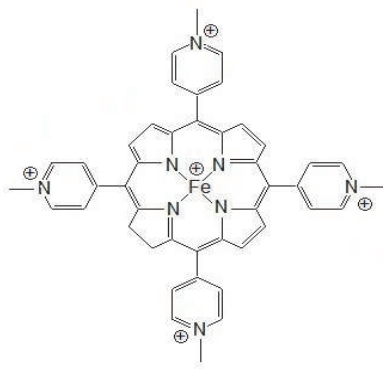

FeTM-4-PyP ${ }^{5+}$

Fig. 10. Metalloporphyrins reported as radical scavengers

\subsection{Photodiagnosis}

The intriguing "tumor-localization" nature of porphyrins prompted the development of porphyrin-based diagnostic pharmaceuticals for different imaging modalities (Lipson, 1961; Nelson, 1991) or radioactive tracers (Nakajima et al., 1993) for tumor detection with encouraging results (Lee et al., 2010).

\subsubsection{Contrast media for MRI}

Magnetic resonance imaging (MRI) with molecular probes offers the potential to monitor physiological parameters with high spatial and temporal resolution, but the construction of cell-permeable imaging agents remains a challenge. Membrane permeability, optical activity, and high relaxivity of porphyrin-based contrast agents offer exceptional functionality for in-vivo imaging. It was recently shown that a porphyrin-based MRI molecular imaging agent, Mn-(DPA- $\left.\mathrm{C}_{2}\right)_{2}-\mathrm{TPPS}_{3}$, effectively penetrates cells and persistently stains living brain tissue in intracranially injected rats. Due to cromogenicity, its distribution can also be observed by histology (Chen, 1984; Lee, 2010; Shahbazi-Gahrouei, 2001).

Porphyrin-based complexes were also identified as necrosis-avid contrast agents (NACAs) for noninvasive MRI identification of acute myocardial infarction, assessment of tissue or organ viability, and therapeutic evaluation after interventional therapies (Ni, 2008).

\subsubsection{NIR fluorescent probes}

The NIR region of the spectrum offers considerable opportunities for diagnosis because of the lack of interference with endogenous absorbers such as haeme pigments and melanin. In this region, light is able to penetrate deeper into tissue, thus offering routes to the therapy of blood vessel disorders and larger or deeper seated malignancies.

Although the greatest activity in the synthesis of NIR-absorbing compounds for therapeutic intent has come from the porphyrin area, with bacteriochlorins and texaphyrins being promising derivatives, none of them is yet in everyday use (Wainwright M., 2010).

\section{Current limitations and future trends}

Only a small part of the impressive number of synthesized porphyrinic compounds is highly efficient in PDT, so the quest for the ideal photosensitizer still continues. 


\subsection{Coupling with light sources}

Several porphyrin related photosensitizers are currently on the market. Unfortunately, they have several limitations. The perfect balance and fulfilment of the criteria displayed in Table 1 , is not reached at this stage of development. The light sources, especially lasers, are increasingly acquiring improved characteristics, so more and more photosynthetizers can be used in biomedical applications and consequently an increased number of tumors are targeted. Future developments in porphyrinic-type photosensitizers will be oriented toward interdisciplinary applications. The improvement of lasers, mainly with increased tissue penetrability, will be associated with the significant development of new photosensitizers, not necessarily related to porphyrins.

\subsection{Dosimetry of PDT}

Despite promising in vitro studies, many attempts to use PDT in the clinic have led to inadequate tumor response or unacceptable side-effects, and this is partially due to the complexity of PDT mechanisms and the associated dosimetry problems. We must take into account that the local concentration of photosensitizer varies within the body and interindividual variability is registered. The penetration of light into the target depends on the specific optical properties of particular tissues. If the tissue is hypoxic, or becomes hypoxic due to PDT, the yield of singlet oxygen will be lower than expected. Therefore, development of accurate modeling tools, definition of PDT "dose" and in vivo measurements are nowadays major challenges in PDT.

\subsection{Oxygen and singlet oxygen}

Target tissue oxygenation is one of the essential factors coupled with the photosensitizers behavior (Patterson M.S. \& Mazurek E., 2010; Ogilby P.R., 2010; Wilson et al., 2007). Oxygen can be measured invasively using implanted oxygen electrodes. But, as demonstrated in radiotherapy studies, the spatial distribution can be highly non-uniform. Non-invasive methods based on magnetic resonance or optical absorption spectroscopy can provide indirect measures of oxygen concentration, and were associated with porphyrins and related structures (Yu et al., 2005).

Singlet oxygen remains at the cutting-edge of modern science, particularly in photosensitised systems. Singlet oxygen brings together seemingly disparate issues such as nanoparticle-dependent surface plasmon resonances and genetically engineered protein tagging experiments.

The conventional method used for direct singlet oxygen measurement is the detection of the weak phosphorescence emitted at $1270 \mathrm{~nm}$ when singlet oxygen returns to the ground state. Upon laser excitation the singlet oxygen emission decay is detected at a $90^{\circ}$ geometry with a germanium photodiode working at room temperature. Luminescence intensity at a time, $t$, after laser pulse is measured for the compound under study and for a reference compound with known singlet oxygen quantum yield on the desired solvent and matched optical density. Accurate calibration curves, with linear dependence of singlet oxygen emission intensity versus laser energy are obtained and a comparison of the slopes for the sample and those of the reference yields the singlet oxygen quantum yield. (Oliveira A.S. et al. 2009 and Santos P.F. et al. 2003, 2004, 2005). Nowadays it is already possible to "see" the spectra of singlet oxygen emission in the NIR region using a cooled IndiumGaliumArseniate (InGaAs) Carged Coupled Device (CCD) detector in the arrangement above described (Oliveira A.S. et al. 2011). 
The cumulative singlet oxygen signal measured during PDT of cell suspensions correlated well with cell survival over a range of treatment conditions. Unfortunately, local concentration of singlet oxygen is in the picomolar range due to its rapid reaction with biomolecules (emission of only about $10^{8}$ photons $\mathrm{cm}^{-3} \mathrm{~s}^{-1}$ ) and the biological microenvironment might influence the real $1270 \mathrm{~nm}$ emission. Accordingly, the instrumentation for detecting such weak luminescence is relatively complex and expensive. Lately, an effective method, Singlet Oxygen Luminescence Dosimetry (SOLD) for quantitative PDT related photobiological studies was evaluated and considered as optimal tool to evaluate photosensitizers in correlation with delivery methods (Jarvi et al., 2006).

The group of Zhang (2008) increased the generation of singlet oxygen via electric-field metalphotosensitizer interactions, taking advantage of near-field interactions of fluorophores with metallic nanoparticles, a phenomenon called metal-enhanced fluorescence (MEF). Nonradiative energy transfer occurs from excited distal fluorophores to the surface plasmon electrons on noncontinuous films. The surface plasmons in turn radiate the photophysical characteristics of the coupling fluorophores. However, additional work is required to optimize or control the amount of singlet oxygen generation from photosensitizers in proximity to metal nanoparticles. Molecular Probes (Invitrogen Inc.) developed the Singlet Oxygen Sensor Green reagent, which is highly selective for singlet oxygen. It exhibits initially weak blue fluorescence, with excitation peaks at 372 and $393 \mathrm{~nm}$ and emission peaks at 395 and $416 \mathrm{~nm}$. In the presence of singlet oxygen, it emits a green fluorescence similar to that of fluorescein (excitation/ emission maxima $\sim 504 / 525 \mathrm{~nm}$ ). Unfortunately, the reagent has only in vitro applications and is used only for cumulative measurements.

Price et al (2009) showed that 3 '- $p$ - (aminophenyl) fluorescein (APF) is adequate for the detection of singlet oxygen and hydroxyl radical under conditions relevant to PDT, in cell-free studies and in cultured L1210 cells photosensitized with benzoporphyhrin. Studies have to be performed in the presence and absence of DMSO to eliminate hydroxyl radical contribution.

The group of Lee S (2010) developed two instruments, an ultra-sensitive singlet oxygen point sensor and a 2D imager, as real-time dosimeters for PDT researchers. The 2D imaging system can visualize in vitro and in vivo spatial maps of both the singlet oxygen production and the localization of the photosensitizer in a tumor during PDT.

\subsection{Photosensitizer delivery}

Penetration of the photosensitizer into tissues is the major limiting factor in PDT. Porphyrinlike molecules are polycyclic, often heavily charged and in many cases insoluble in both hydrophilic and lipophilic media. In addition, porphyrins and their analogues are known to self-aggregate, which is facilitated by a flat, wide, and electron-rich surface, creating van der Waals, $\Pi-\Pi$ stacking, charge-transfer interactions (Andrade et al., 2008). Therefore, finding adequate drug delivery systems is crucial in improving bioavailability, target specificity and cellular localization of photosensitizers in PDT. Drug targeting from parenteral administration of photosensitizers has been achieved by using liposomes, oil emulsions, microspheres, micellar nanoparticles, proteins and monoclonal antibodies, but the ideal formulation has not yet been developed.

Polymeric nanoparticles offer numerous advantages over the conventional drug delivery systems including high drug loading, controlled release, and a large variety of carrier materials and pharmaceutical formulations (Konan, 2002).

In the development of new drug delivery principles and devices, one may take advantage of the very basics of PDT, namely photoactivation. The method provides a broad range of 
adjustable parameters (e.g., wavelength, intensity, duration, spatial and temporal control) that can be optimized to suit a given application. Photoactivated drug delivery can be used to control the release rate of the active principle from a dosage form (i.e., a carrier system), to activate a drug molecule that is already present at the site of action in an inactive form (e.g., a photosensitizer or a prodrug), or it can combine the two (i.e., photocontrolled drug release and drug activation). While photoactivation of sensitizers is well established, the application of photoactivated carrier systems offers new opportunities, including photoresponsive hydrogels, microcapsules, liposomes, nanoparticles and oligonucleotides (Sortino, 2008).

As shown recently by Kishwar et al. (2010), ZnO nanorods proved to be an efficient light system attached to a photosensitizer for intracellular necrosis. Zinc oxide $(\mathrm{ZnO})$ has many advantageous properties like direct band gap of $3.37 \mathrm{eV}$, large exciton binding energy of $60 \mathrm{eV}$ at room temperature and deep level defects emissions that cover the whole visible range. The $\mathrm{UV}$ and green emission part of the white light of $\mathrm{ZnO}$ can be used for the activation of photosensitizers in PDT. The family of $\mathrm{ZnO}$ nanostructures is the richest known so far and the growth of these nanostructures is facilitated by the self organized growth property of this material. Being a bio-safe and bio-compatible material, $\mathrm{ZnO}$ is an attractive candidate for biomedical applications. $\mathrm{ZnO}$ nanorods grown on the femto tip were shown to deliver the photosensitizer to breast cancerous cells and cause necrosis within few minutes. Topical pain caused by the conventional PDT method can be reduced by this technique.

\subsection{Increased fluorescence for photodiagnosis}

There is a tremendous need for developing novel non-invasive or minimally invasive diagnostic tools for assessing cell/tissue metabolism and functions, in order to discriminate pathological disturbances in early disease stages. The capability to visualize pathologic tissues as first step before surgical procedure or therapy, may clearly increase treatment efficacy.

Intensive research is done to get probes with appropriate fluorescence characteristics (high quantum yield, large Stokes shifts, reduced photolability and great suitability for cells and tissues, i.e., well-balanced amphiphyllic character, low or no intrinsic toxicity, higher excitation wavelengths to prevent spectral interferences due to the auto fluorescence of the biological samples). Due to the adequacy of their properties, the use of porphyrins and metalloporphyrins as near infrared probes (NIR probes) in biomedical applications increased exponentially. Porphyrinic structures, either in solution or in restricted nanometric geometries, typically display long decay times, and this can be used as an extra discrimination advantage for fluorescence imaging (long lifetime probes for lifetime based sensing). We believe that nowadays the analysis of porphyrins and porphyrin-like structures from the point of view of their fluorescence properties is crucial for developing minimally invasive fluorescent tools for diagnosis.

Several studies on fluorescent photosensitizers show them as markers and beacons and point toward their dual utility for "seeing and treating" (Chen et al., 2005; Cló et al., 2007). Theranostic nanomedicine, integrating nano-platforms which can diagnose, deliver targeted therapy and monitor response to therapy, is best illustrated in PDT. Photosensitizers will not only kill pathologic cells when light-activated, but being inherently fluorescent they can be used for imaging and locating disease as photosensitizers selectively accumulate within diseased tissue. The use of lasers and minimally invasive fiber optic tools, along with the development of new agents that respond to NIR wavelengths for better tissue penetration, makes direct targeting of deep tissues possible, enabling imaging and treatment of several pathologies. Alongside, nanoprobes have been developed for in vivo optical imaging, which include quantum dots, 
up-converting nanophosphors, gold and silica nanoparticles, and photosensitizers containing nanoparticulate carriers. This approach is becoming of increasing interest for oncological applications, addressing the challenges of cancer heterogeneity and adaptability.

\subsection{Nano PDT}

The general advances in medicine and the progress in the use of photosensitizers for PDT directed the research towards the development of photoactive nanoparticles which can be used for cancer therapy, as sensors for tumor indication and imaging and for other applications of PDT such as vascular disorders (Paszko et al., 2011). The effectiveness of PDT could be maximised by using nanoparticles which can improve the photosensitizer solubility in aqueous media, its formulation properties and selectivity to the target tissue. Selectivity improvement can be achieved by nano-formulating the photosensitizers with liposomes or by modifying them using dendrimers, nanotubes (Zhu, 2008) or fullerenes; such liposomal formulation of Foscan (Foslip $®$ ) is currently under investigation (Buchholz, cited by Lassale et al., 2008).

\section{Conclusions}

Porphyrins have a well-defined place among the substances used in biomedical engineering as medical devices (as defined by the European Council directives No. 93/42/EEC and 98/79/EC, completed by the associated MEDDEV guidance documents) as they can be used effectively as both diagnosis and treatment tools.

\begin{tabular}{|c|c|c|c|c|}
\hline No & Target & $\begin{array}{c}\text { Drug/Procedure/ } \\
\text { Device }\end{array}$ & Theme & Status \\
\hline 1. & Colorectal Cancer & Optical Fluoroscopy & $\begin{array}{c}\text { Colorectal Cancer Detection by Means of Optical } \\
\text { Fluoroscopy }\end{array}$ & \multirow{3}{*}{ Recruiting } \\
\hline 2. & $\begin{array}{c}\text { Porphyria Cutanea } \\
\text { Tarda } \\
\end{array}$ & Exjade & $\begin{array}{l}\text { Safety and Efficacy of Oral Deferasirox in Patients } \\
\text { With Porphyria Cutanea Tarda }\end{array}$ & \\
\hline 3. & Glioma & 5-Aminolevuline Acid & $\begin{array}{c}\text { Safety Study of Aminolevulinic Acid (ALA) to } \\
\text { Enhance Visualization and Resection of Malignant } \\
\text { Tumors of the Brain }\end{array}$ & \\
\hline 4 & Lung Cancer & CyPath & $\begin{array}{c}\text { Sputum Labeling Utilizing Synthetic Meso Tetra (4- } \\
\text { Carboxyphenyl) Porphine (TCPP) for Detection of } \\
\text { Lung Cancer }\end{array}$ & Active \\
\hline 5. & Acne Vulgaris & Visonac & $\begin{array}{c}\text { Photoactive Porphyrins (PAP) Levels After Topical } \\
\text { Visonac Application in Acne Patients }\end{array}$ & \multirow{7}{*}{ Completed } \\
\hline 6. & $\begin{array}{l}\text { Basal Cell } \\
\text { Carcinoma }\end{array}$ & $\begin{array}{c}\text { PDT with Metvix } 160 \\
\text { mg/g cream } \\
\text { PDT with placebo } \\
\text { cream }\end{array}$ & $\begin{array}{c}\text { Photodynamic Therapy (PDT) With Metvix Cream } \\
160 \mathrm{mg} / \mathrm{g} \text { Versus PDT With Placebo Cream in } \\
\text { Patients With Primary Nodular Basal Cell } \\
\text { Carcinoma }\end{array}$ & \\
\hline 7. & $\begin{array}{l}\text { Basal Cell } \\
\text { Carcinoma }\end{array}$ & $\begin{array}{c}\text { PDT with Metvix } \\
160 \mathrm{mg} / \mathrm{g} \text { cream and } \\
\text { Placebo cream }\end{array}$ & $\begin{array}{c}\text { PDT With Metvix } 160 \mathrm{mg} / \mathrm{g} \text { Cream Versus PDT } \\
\text { With Placebo Cream in Patients With Primary } \\
\text { Nodular Basal Call Carcinoma }\end{array}$ & \\
\hline 8. & Porphyria & $\begin{array}{c}\text { Heme arginate; } \\
\text { Tin mesoporphyrin }\end{array}$ & $\begin{array}{c}\text { Phase I/II Study of Heme Arginate and Tin } \\
\text { Mesoporphyrin for Acute Porphyria }\end{array}$ & \\
\hline 9. & Healthy Subjects & $\begin{array}{c}\text { Eltrombopag; } \\
\text { Ciprofloxacin; Placebo }\end{array}$ & $\begin{array}{l}\text { Study In Healthy Subjects To Evaluate The Photo- } \\
\text { Irritant Potential Of Eltrombopag }\end{array}$ & \\
\hline 10. & $\begin{array}{l}\text { Basal Cell } \\
\text { Carcinoma }\end{array}$ & $\begin{array}{c}\text { Procedure: PDT with } \\
\text { Metvix } 160 \mathrm{mg} / \mathrm{g} \\
\text { cream }\end{array}$ & $\begin{array}{c}\text { Metvix PDT in Patients With "High Risk" Basal Cell } \\
\text { Carcinoma }\end{array}$ & \\
\hline 11. & Porphyria & $\begin{array}{c}\text { Heme arginate; } \\
\text { Tin mesoporphyrin }\end{array}$ & $\begin{array}{l}\text { Studies in Porphyria III: Heme and Tin } \\
\text { Mesoporphyrin in Acute Porphyrias }\end{array}$ & \\
\hline
\end{tabular}

Table 5. Current status of medical trials involving porphyrins (source: ClinicalTrials.gov) 
To underline the importance of porphyrinic compounds and to reveal again their multivalency toward biomedical applications we present the current status (2011, April) of their involvement in a wide range of medical trials of the U.S. National Institutes of Health (see Table 5).

\section{Acknowledgements}

The work was performed within the frame of MNT-Era-Net projects No. 7-030/ 2010 (CNMP), 0003/2009 and 0004/2009 (FCT).

\section{References}

*** ClinicalTrials, available on http://clinicaltrials.gov/

*** Directive 98/79/EC of the European Parliament and of the Council of 27 October 1998 on in vitro diagnostic medical devices

*** European Council directive 93/42/EEC of 14 June 1993 concerning medical devices

*** Molecular Probes Handbook, available on http://www.invitrogen.com/site/us/en/ home/brands/Molecular-Probes.html

Adler A.D, Longo F.R, Finarelli J.D, Goldmacher J, Assour J, Korsakoff L (1976). Journal of Organic Chemistry Vol. 32 No.2 (February), pp. 476-476, ISSN 1434-193X, doi: 10.1021/jo01288a053

Allison R.R., Downie G.H., Cuenca R., Hu X.H., Childs C.J.H., Sibata C.H. (2004). Photosensitizers in clinical PDT. Photodiagnosis and Photodynamic Therapy Vol. 1, pp. 27-42, ISSN 0031-8655, doi: 10.1016/S1572-1000(04)00039-0.

Allison R., Sibata C. (2010). Oncologic photodynamic therapy photosensitizers: A clinical review. Photodiagnosis and Photodynamic Therapy, Vol. 7 No.2 (June), pp. 61-75, ISSN 0031-8655 doi: 10.1016/j.pdpdt.2010.02.001

Alves E., Costa L., Carvalh C.M.B., Tomé J.P.C., Faustino M.A., Neves M.G.P.M.S., Tomé A.C., Cavaleiro J.A.S., Cunh Â., Almeida A. (2009). Charge effect on the photoinactivation of Gram-negative and Gram-positive bacteria by cationic mesosubstituted porphyrins. BMC Microbiology Vol. 9:70, ISSN 1471-2180, doi:10.1186/1471-2180-9-70

Anand S., Honari G., Hasan T., Elson P., Maytin E.V. (2009). Low-dose Methotrexate Enhances Aminolevulinate-based Photodynamic Therapy in Skin Carcinoma Cells In vitro and In vivo. Clinical Cancer Research Vol. 15 No. 10 (May 15), pp. 3333-3343, ISSN: 1078-0432, doi: 10.1158/1078-0432.CCR-08-3054

Andrade S.M., Teixeira R., Costa S.M.B., Sobral A.J.F.N. (2008). Self-aggregation of free base porphyrins in aqueous solution and in DMPC vesicles. Biophysical Chemistry Vol. 133 No 1-3 (March), pp 1-10, ISSN 0301-4622, doi: 10.1016/j.bpc.2007.11.007

Awan M.A., Tarin S.A.(2006). Review of photodynamic therapy. The Surgeon. Vol.4 No.4 (August) pp. 231-236, ISSN 1479-666X, doi: 10.1016/S1479-666X(06)80065-X.

Banerjee S., Das T., Samuel G., Sarma H.D., Venkatesh M., Pillai M.R. (2001). A novel [186/188Re]-labelled porphyrin for targeted radiotherapy. Nuclear Medicine Communication Vol. 22 No. 10 (October), pp. 1101-1107, ISSN 0143-3636.

Barth R.F., Coderre J.A., Vicente M.G., Blue T.E. (2005). Boron neutron capture therapy of cancer: Current status and future prospects. Clinical Cancer Research Vol. 11 No. 11, pp. 3987-4002, ISSN: 1078-0432. 
Batinić-Haberle, I.; Benov, L.; Spasojević, I.; Hambright, P.; Crumbliss, A. L., Fridovich I. (1999). The relationship between redox potentials, proton dissociation constants of pyrrolic nitrogens, and in vitro and in vivo superoxide dismutase activities of manganese(III) and iron(III) cationic and anionic porphyrins. Inorganic Chemistry Vol. 38 No. 18 (August 17), pp 4011-4022, ISSN 0020-1669, doi: 10.1021/ic990118k

Berenbaum M.C. \& Bonnett, R. (1990). in Photodynamic Therapy of Neoplastic Disease, Kessel, D. (Ed.), Vol. 2, pp. 169, CRC Press, ISBN 978-0849358166, Boca Raton, Boston.

Bonnett, R. (2000). Chemical aspects of Photodynamic Therapy, Gordon \& Breach Publishers, ISBN 9056992481 Amsterdam

Boscencu R., Socoteanu R, Oliveira A.S., Vieira Ferreira L.F., Nacea V., Patrinoiu G. (2008). Synthesis and Characterization of Some Unsymmetrically-substituted Mesoporphyrinic Mono-Hydroxyphenyl Complexes of Copper(II). Polish Journal of Chemistry Vol 82, No. 3, pp. 509-521, ISSN 0137-5083

Boscencu R., Socoteanu R., Ilie M., Oliveira A. S., Constantin C., Vieira Ferreira L. F. (2009). Synthesis, spectral and biological evaluation of some mesoporphyrinic $\mathrm{Zn}$ (II) complexes, Revista de Chimie Vol. 60 No. 10, pp 1006-1011, ISSN 0034-7752

Boscencu R., Ilie M., Socoteanu R., Oliveira A. S., Constantin C., Neagu M., Manda G., Vieira Ferreira L. F. (2010). Microwave Synthesis, Basic Spectral and Biological Evaluation of Some Copper (II) Mesoporphyrinic Complexes, Molecules Vol. 15 No.5, pp. 37313743, ISSN 1420-3049, doi:10.3390/molecules15053731

Bregadze V.I., Sivaev I.B., Gabel D., Wohrle D. (2001). Polyhedral boron derivatives of porphyrins and phthalocyanines. Journal of Porphyrins \& Phthalocyanines Vol. 5 No. 11 (November), pp. 767-781, ISSN 1088-4246, doi: 10.1002/jpp.544.

Brunner H., Gruber N. (2004). Carboplatin-containing porphyrin-platinum complexes as cytotoxic and phototoxic antitumor agents, Inorganica Chimica Acta Vol. 357, No. 15 (December 1), pp. 4423-4451, ISSN 0020-1693, doi: 10.1016/j.ica.2004.03.061

Buytaert E., Callewaert G., Hendrickx N., Scorrano L., Hartmann D., Missiaen L., Vandenheede J.R., Heirman I., Grooten J., Agostinis P. (2006). Role of endoplasmic reticulum depletion and multidomain proapoptotic BAX and BAK proteins in shaping cell death after hypericin-mediated photodynamic therapy. FASEB J Vol. 20 No.6 (April), pp.756-758, ISSN 0892-6638, doi: 10.1096/fj.05-4305fje

Capella M.A.M., Capella L.S. (2003). A light in multidrug resistance: Photodynamic treatment of multidrug-resistant tumors. Journal of Biomedical Science Vol. 10 No.4, pp 361-366, ISSN 1021- 7770, doi: 10.1007/BF02256427

Castano A.P., Mroz P., Hamblin M.R. (2006). Photodynamic therapy and anti-tumour immunity. Nature Reviews. Cancer 2006; Vol 6 (July), pp 535-545, ISSN 1474-175X, doi: $10.1038 /$ nrc1894.

Chauhan S.M. S., Sahoo B.B., Srinivas K.A. (2001). Microwave-Assisted Synthesis of 5,10,15,20-Tetraaryl Porphyrins. Synthetic Communications: An International Journal for Rapid Communication of Synthetic Organic Chemistry, Vol. 31, No. 1 pp. 33 - 37, ISSN 0039-7911, doi: 10.1081/SCC-100000176

Che C.M., Sun R.W., Yu W.Y., Ko C.B., Zhu N., Sun H. (2003). Gold(III) porphyrins as a new class of anticancer drugs: cytotoxicity, DNA binding and induction of apoptosis in human cervix epitheloid cancer cells. Chemical Communications Vol. 21, No.14 pp. 1718 - 1719 ISSN 1359-7345, doi: 10.1039/B303294A. 
Chen C., Cohen J.S., Myers C.E., Sohn M. (1984). Paramagnetic metalloporphyrins as potential contrast agents in NMR imaging. FEBS Letters Vol. 168 No.1 (March12), pp. 70-74, ISSN 0014-5793, doi: 10.1016/0014-5793(84)80208-2.

Chen Y., Gryshuk A., Achilefu S., Ohulchansky T., Potter W., Zhong T., Morgan J., Chance B., Prasad P.N., Henderson B.W., Oseroff A., Pandey R.K. (2005). A novel approach to a bifunctional photosensitizer for tumor imaging and phototherapy. Bioconjugate Chemistry Vol. 16 No. 5, pp. 1264-1274, ISSN 1043-1802, doi: 10.1021/bc050177o

Chmielewski P.J.; Latos-Grażyński L., Rachlewicz K. (1995). 5,10,15,20Tetraphenylsapphyrin - Identification of a Pentapyrrolic Expanded Porphyrin in the Rothemund Synthesis. Chemistry. A European Journal Vol. 1 No.1 (April), pp. 6873, ISSN 0947-6539, doi: 10.1002/chem.19950010111

Cló E., Snyder J.W., Ogilby P.R., Gothelf K.V. (2007). Control and selectivity of photosensitized singlet oxygen production: challenges in complex biological systems. Chembiochem Vol. 8 No. 5, pp 475-81, ISSN 1439-7633, doi: 10.1002/cbic.200600454.

Dewaele M., Verfaillie T., Martinet W., Agostinis P. (2010). Death and survival signals in photodynamic therapy. Methods in Molecular Biology Vol. 635 pp. 7-33, ISSN 10643745, doi: 10.1007/978-1-60761-697-9_2

Dickson E.F.G., Goyan R.L., Pottier R.H. (2002) New directions in photodynamic therapy. Cellular and Molecular Biology Vol. 48 No.8, pp. 939-954, ISSN 0145-5680.

Dogutan D.K., Zaidi S.H.H., Thamyongkit P., Lindsey J. S. (2007). New Route to ABCDPorphyrins via Bilanes. Journal of Organic Chemistry Vol. 72 No. 20 (September), ISSN 1434-193X, doi: 10.1021/jo701294d

Dolmans D., Fukumura D., Jain R.K. (2003). Photodynamic therapy for cancer. Nature Reviews. Cancer Vol. 3 No.5, pp. 380-387, ISSN 1474-175X, doi: 10.1038/nrc1071

Dougherty T.J. (1987). Photosensitizers: therapy and detection of malignant tumors Photochemistry and Photobiology, Vol. 45, Supplement 1 (May) pp. 879-889, ISSN 0031-8655, doi: 10.1111/j.1751-1097.1987.tb07898.x

Dougherty T.J., Gomer C.J., Henderson B.W., Jori G., Kessel D., Korbelik M., Moan J., Peng Q. (1998). Photodynamic therapy. Journal of the National Cancer Institute Vol. 90, No. 12, pp 889-905, ISSN 0027-8874.

Dysart J.S., Singh G., Patterson M.S. (2005). Calculation of singlet oxygen dose from photosensitizer fluorescence and photobleaching during mTHPC photodynamic therapy of MLL cells. Photochemistry and Photobiology Vol. 81, No 1 (January), pp 196-205, ISSN 0031-8655, doi: 10.1111/j.1751-1097.2005.tb01542.x

Evstigneeva R.P., Zaitsev A.V., Luzgina V.N., Ol'shevskaya V.A., Shtil A.A. (2003). Carboranylporphyrins for boron neutron capture therapy of cancer. Current Medicinal Chemistry - Anti-Cancer Agents Vol. 3 No. 6 (November), pp. 383-392, ISSN 1568-0118.

Fayter D., Corbett M., Heirs M., Fox D., Eastwood A. (2010). A systematic review of photodynamic therapy in the treatment of pre-cancerous skin conditions, Barrett's oesophagus and cancers of the biliary tract, brain, head and neck, lung, oesophagus and skin. Health Technology Assessment Vol. 14 No. 37 (July), pp. 1-288, ISSN 13665278, doi: 10.3310/hta14370 
Garg A.D., Nowis D., Golab J., Agostinis P. (2010). Photodynamic therapy: illuminating the road from cell death towards anti-tumour immunity. Apoptosis. Vol. 15 No. 9 (September), pp 1050-71, DOI: 10.1007/s10495-010-0479-7

Garg A.D., Krysko D.V., Vandenabeele P., Agostinis P. (2011). DAMPs and PDT-mediated photo-oxidative stress: exploring the unknown. Photochemical $\mathcal{E}$ Photobiological Sciences ISSN 1474-905X, doi: 10.1039/C0PP00294A (Epub ahead of print)

Gollnick S.O., Vaughan L., Henderson B.W. (2002). Generation of effective antitumor vaccines using photodynamic therapy, Cancer Research Vol. 62 No.6 (March 15), pp. 1604-8, ISSN 0008-5472.

Gottumukkala V., Luguya R., Fronczek F.R., Vicente M.G.H. (2005). Synthesis and cellular studies of an

octa-anionic 5,10,15,20-tetra[3,5(nidocarboranylmethyl)phenyl]porphyrin (H2OCP) for application in BNCT. Bioorganic \& Medicinal Chemistry Vol. 13 No. 5 (March 1), pp. 1633-1640, ISSN 09680896, doi: 10.1016/j.bmc.2004.12.016.

Guo C.C., Li H. P., Zhang X. B. (2003). Study on synthesis, characterization and biological activity of some new nitrogen heterocycle porphyrins. Bioorganic $\mathcal{E}$ Medicinal Chemistry, Vol. 11 No. 8 (April), pp. 1745-1751, ISSN 09680896, doi: 10.1016/S09680896(03)00027-0.

Guo C.C., R. B. Tong, K. L. Li (2004). Chloroalkyl piperazine and nitrogen mustard porphyrins: synthesis and anticancer activity. Bioorganic \& Medicinal Chemistry, Vol. 12 No. 9 (April), pp. 2469-2475, ISSN 09680896, doi: 10.1016/j.bmc.2004.01.045.

Halime Z., Belieu S, Lachkar M., Roisnel T., Richard P., Boitrel B. (2006). Functionalization of Porphyrins: Mechanistic Insights, Conformational Studies, and Structural Characterizations, Eur. J. Org. Chem. 2006, Nr. 5, 1207-1215, ISSN 1099-0690; DOI: 10.1002/ ejoc. 200500685

Hancock R.E.W. (2007). The end of an era? Nature Reviews Drug Discovery, Vol. 6 No. 28 (January), ISSN 1474-1776, doi: 10.1038/nrd2223.

He H., Zhou Y., Liang F., Li D., Wu J., Yang L., Zhou X., Zhang X., Cao X. (2006). Combination of porphyrins and DNA-alkylation agents: Synthesis and tumor cell apoptosis induction Bioorganic \& Medicinal Chemistry. Vol. 14 No.4 (February), pp. 1068-1077, ISSN 09680896, doi: 10.1016/j.bmc.2005.09.041.

Hryhorenko E.A., Oseroff A.R., Morgan J., Rittenhouse-Diakun K. (1998). Antigen specific and nonspecific modulation of the immune response by aminolevulinic acid based photodynamic therapy. Immunopharmacology Vol. 40 No. 3 (November), pp. 231240, ISSN 0892-3973, doi: 10.1016/S0162-3109(98)00047-2.

Jarvi M. T., Niedre M.J., Patterson M.S., Wilson B.C. (2006). Singlet Oxygen Luminescence Dosimetry (SOLD) for Photodynamic Therapy: Current Status, Challenges and Future Prospects. Photochemistry and Photobiology Vol. 82 No. 5 (September), pp. 1198-1210, ISSN 0031-8655, doi: 10.1562/2006-05-03-IR-891.

Jori G., Coppellotti O. (2007). Inactivation of pathogenic microorganisms by photodynamic techniques: mechanistic aspects and perspective applications. Anti-infective Agents in Medicinal Chemistry, Vol. 6 No.2. (April), pp. 119-131, ISSN 1871-5214.

Kadish K., Guilard R., Smith K.M. Eds. 2002 The Porphyrin Handbook Series, Vols. 1-20, Academic Press, available at http://www.icpp.uh.edu/Documents/Porphyrin_Handbook_030305b.pdf 
Kessel D., Vicente M.G., Reiners J.J. Jr. (2006). Initiation of apoptosis and autophagy by photodynamic therapy. Lasers in Surgery \& Medicine Vol.38 No.5 (June), pp. 482488, ISSN 0196-8092, doi: 10.1002/1sm.20334

Kessel D. \& Reiners Jr. J.J. (2007). Apoptosis and Autophagy After Mitochondrial or Endoplasmic Reticulum Photodamage. Photochemistry \& Photobiology Vol. 83 No.5 (September-October), pp. 1024-1028, ISSN 0031-8655 doi: 10.1111/j.17511097.2007.00088.x.

Kishwar S., Asif M.H., Nur O., Willander M., Larsson P.O. (2010). Intracellular ZnO Nanorods Conjugated with Protoporphyrin for Local Mediated Photochemistry and Efficient Treatment of Single Cancer Cell. Nanoscale Research Letters Vol. 5 No.10, pp. 1669-1674, ISSN 1556-276X, doi: 10.1007/s11671-010-9693-z.

Konan Y.N., Gurny R., Allemann E. (2002). State of the art in the delivery of photosensitizers for photodynamic therapy. Journal of Photochemistry and Photobiology B: Biology Vol. 66 No. 2 (March), pp. 89-106, ISSN 1011-1344, doi: 10.1016/S1011-1344(01)00267-6

Konopka K., Goslinski T. (2007). Photodynamic therapy in dentistry. Journal of Dental Research. Vol. 86 no. 8 (August), pp. 694-707, ISSN 0022-0345, doi: $10.1177 / 154405910708600803$.

Konopka K., Goslinski T. (2008). Prospects for photodynamic therapy in dentistry. Biophotonics International, Vol 15 No. 7 (July), pp. 32-35, ISSN 1081-8693.

Lapes M., Petera J., Jirsa M. (1996). Photodynamic therapy of cutaneous metastases of breast cancer after local application of meso-tetra-(para-sulphophenyl)-porphyrin (TPPS4) Journal of Photochemistry \& Photobiology B: Biology Vol. 36 No. 2 (November), pp. 205-207, ISSN 1011-1344, doi: 10.1016/S1011-1344(96)07373-3

Lassalle H.P., Wagner M., Bezdetnaya L., Guillemin F., Schneckenburger H.: (2008). Fluorescence imaging of Foscan ${ }^{\circledR}$ and Foslip in the plasma membrane and in whole cells. Journal of Photochemistry and Photobiology B: Biology Vol. 92 No.1 (July 24), pp 45-73, ISSN 1011-1344, doi:10.1016/j.jphotobiol.2008.04.007

Lee S., Galbally-Kinney K.L., Murphy B.A., Davis S.J., Hasan T., Spring B., Yupeng T., Pogue B.W., Isabelle M.E., O'Hara J.A. (2010). In vivo PDT dosimetry: singlet oxygen emission and photosensitizer fluorescence. Progress in biomedical optics and imaging Vol. 11 No.4, ISSN 1605-7422

Lee T., Zhang X., Dhar S., Faas H., Lippard S.J., Jasanoff A. (2010). In Vivo Imaging with a Cell-Permeable Porphyrin-Based MRI Contrast Agent. Chemistry \& Biology, Vol. 17 No 6 (June 25), pp. 665-673, ISSN 1074-5521, doi: 10.1016/j.chembiol.2010.05.009.

Lin W., Peng D., Wang B., Long L., Guo C., Yuan J. (2008). A Model for Light-Triggered Porphyrin Anticancer Prodrugs Based on an o-Nitrobenzyl Photolabile Group. European Journal of Organic Chemistry No. 5 (February), pp 793-796, ISSN 1434193X, doi: 10.1002/ ejoc.200700972.

Lindsey J.S. (2010). Synthetic Routes to meso-Patterned Porphyrins, Accounts of Chemical Research, Vol. 43, No. 2 (October), pp. 300-311, doi 10.1021/ar900212t

Hsu H.C., Schreiman I.C. (1986). Synthesis of Tetraphenylporphyrins Under Very Mild Conditions, Tetrahedron Letters Vol. 27, No. 41, pp. 4969-4970, ISSN 0040-4039, doi: 10.1016/S0040-4039(00)85109-6.

Lindsey J.S., Schreiman I.C., Hsu H.C., Kearney P.C., Marguerettaz A.M. (1987). Rothemund and Adler-Longo Reactions Revisited: Synthesis of Tetraphenylporphyrins Under 
Equilibrium Conditions, Journal of Organic Chemistry, Vol. 52 No.5, 827-836 , ISSN 1434-193X, doi: 10.1021/jo00381a022.

Lipson R.L., Baldes E.J., Olsen A.M. (1961). Hematoporphyrin derivative: A new aid for endoscopic detection of malignant disease. Journal of Thoracic Cardiovascular Surgery, Vol. 42 (November), pp 623-629, ISSN 0022-5223.

Liu M.O., Tai C.H., Hu A.T. (2005). Synthesis of metalloporphyrins by microwave irradiation and their fluorescent properties. Materials Chemistry and Physics, Vol. 92 No. 2-3 (August 15), pp. 322-326, ISSN 0254-0584, doi: 10.1016/j.matchemphys.2004.09.027.

Longo F.R., Finarelli J.D., Kim J. (1969). The synthesis and some physical properties of mstetra(pentafluorophenyl)-porphin and $m s$-tetra(pentachlorophenyl)porphin. Journal of Heterocyciclic Chemistry Vol. 6 No. 6 (December), pp. 927-931, ISSN 0022-152X, doi: 10.1002/jhet.5570060625.

Lottner C., Bart K.C., Bernhardt G., Brunner H. (2002). Hematoporphyrin-Derived Soluble Porphyrin-Platinum Conjugates with Combined Cytotoxic and Phototoxic Antitumor Activity Journal of Medicinal Chemistry Vol. 45 No 10 (April 17), pp. 20642078, ISSN 0022-2623, doi: 10.1021/jm0110688.

Loupy A., Perreux L., Liagre M., Burle K., Moneuse M. (2001). Reactivity and selectivity under microwaves in organic chemistry. Relation with medium effects and reaction mechanisms. Pure \& Applied Chemistry Vol. 73 No. 1 pp. 161-166, ISSN: 0033-4545.

Maisch T., Szeimies R.-M., Jori G., Abels C. (2004). Photochemical \& Photobiological Sciences Vol. 3 No 10 (October), pp. 907-917, ISSN 1474-905X, doi: 10.1039/B407622B

Maisch T. (2009). A new strategy to destroy antibiotic resistant microorganisms: antimicrobial photodynamic treatment. Mini-Reviews in Medicinal Chemistry Vol. 9 No.8, pp 974-983, ISSN 1389-5575.

Manda G., Nechifor M.T., Neagu T.M. (2009). Reactive Oxygen Species, Cancer and AntiCancer Therapies. Current Chemical Biology, Vol 3 No.1 (January 1), pp. 342-366, ISSN 1872-3136.

Masilamani V., Al-Zhrani K., Al-Salhi M., Al-Diab A., Al-Ageily M. (2004). Cancer diagnosis by autofluorescence of blood components. Journal of Luminescence Vol. 109 No. 3-4 (September), pp.143-154, ISSN 0022-2313, doi: 10.1016/j.jlumin.2004.02.001.

McCoy C.P., Rooney C., Edwards C.R., Jones D.S., Gorman S.P. (2007). Light-Triggered Molecule-Scale Drug Dosing Devices, Journal of American Chemical Society Vol 129 No. 31 (July 18), pp. 9572-9573, ISSN 0002-7863, doi: 10.1021/ja073053q.

Merchat M., Bertolini G., Giacomini P., Villaneuva A.' Jori G. (1996). Meso-substituted cationic porphyrins as efficient photosensitizers of gram-positive and gramnegative bacteria, Journal of Photochemistry \& Photobiology B: Biology, Vol. 32 No 3, pp. 153-157, ISSN 1011-1344, doi: 10.1016/1011-1344(95)07147-4.

Milgrom, L.R. (1983). Synthesis of some new tetra-arylporphyrins for studies in solar energy conversion Journal of the Chemical Society, Perkin Transactions 1., pp. 2535-2539, ISSN 1472-7781, doi: 10.1039/P19830002535.

Mironov A.F., Nizhnik A.N., Nockel A.Y. (1990). Haematoporphyrin derivatives: an oligomeric composition study. Journal of Photochemistry \& Photobiology B: Biology Vol. 4 No. 3 (January), pp. 297-306, ISSN 1011-1344, doi: 10.1016/10111344(90)85035-U 
Moan J., Berg K. (1992). Photochemotherapy of cancer: experimental research. Photochemistry and Photobiology Vol 55, No.6 (June), pp.145-157, ISSN 0031-8655, doi: 10.1111/j.1751-1097.1992.tb08541.x

Moan J., Peng Q. (2003). An outline of the history of PDT. in Photodynamic therapy. Patrice T (Ed.), pp.1-18, The Royal Society of Chemistry, Thomas Graham House, ISBN 9781-84755-165-8, Science Park, Cambridge, UK.

Mroz P., Bhaumik J., Dogutan D.K., Aly Z., Kamal Z., Khalid L., Kee H.L., Bocian D.F, Holten D., Lindsey J.S., Hamblin M.R. (2009). Imidazole metalloporphyrins as photosensitizers for photodynamic therapy: Role of molecular charge, central metal and hydroxyl radical production. Cancer Letters, Vol. 282 No. 1, pp. 63-76, ISSN 0304-3835, doi: 10.1016/j.canlet.2009.02.054.

Nakajima S., Yamauchi H., Sakata I., Hayashi H., Yamazaki K., Maeda T., Kubo Y., Samejima N., Takemura T. (1993). Indium-111-labeled manganesemetalloporphyrin for tumor imaging. Nuclear Medicine $\mathcal{E}$ Biology Vol. 20 No 2 (February), pp. 231-237, ISSN 0969-8051, doi: 10.1016/0969-8051(93)90120-J

Nelson J.A, Schmiedl U. (1991). Porphyrins as contrast media. Magnetic Resonance in Medicine, Vol. 22, No. 2 (December), pp. 366-371, ISSN 0740-3194, doi: 10.1002/mrm.1910220243.

Ni Y. (2008). Metalloporphyrins and Functional Analogues as MRI Contrast Agents Current Medical Imaging Reviews Vol. 4 No. 2 (May), pp 96-112, ISSN 1573-4056, doi: 10.2174/157340508784356789.

O'Connor A.E., Gallagher W.M., Byrne A.T. (2009). Porphyrin and Nonporphyrin Photosensitizers in Oncology: Preclinical and Clinical Advances in Photodynamic Therapy. Photochemistry \& Photobiology, Vol. 85 No. 5 (September/October), pp. 1053-1074, ISSN 0031-8655, doi: 10.1111/j.1751-1097.2009.00585.x.

Ogilby P.R. (2010). Singlet oxygen: there is indeed something new under the sun. Chemical Society Reviews, Vol. 39, pp. 3181-3209, ISSN 0306-0012, doi: 10.1039/B926014P

Ol'shevskaya V.A. Zaitsev A.V., Luzgina V.N., Kondratieva T.T., Ivanov O.G., Kononova E.G., Petrovskii P.V., Mironov A.F., Kalinin V.N., Hofmann J., Shtil A.A. (2006). Novel boronated derivatives of 5,10,15,20-tetraphenylporphyrin: Synthesis and toxicity for drug-resistant tumor cells. Bioorganic \& Medicinal Chemistry Vol.14 No.1(january 1), pp. 109-120, ISSN 09680896, doi: 10.1016/j.bmc.2005.07.067

Oleinick N.L., Morris R.L. \& Belichenko I. (2002) The role of apoptosis in response to photodynamic therapy: what, where, why, and how. Photochemical \& Photobiological Sciences, Vol. 1, pp. 1-21, ISSN 1474-905X, doi: 10.1039/B108586G

Oliveira A.S., Licsandru L., Boscencu R., Socoteanu R., Nacea V., Vieira Ferreira L.V. (2009). A Singlet Oxygen Photogeneration and Luminescence Study of Unsymmetrically Substituted Mesoporphyrinic Compounds. International Journal of Photoenergy, Vol. 2009, article ID 413915, DOI: 10.1155/2009/413915

Oliveira A.S, Ferreira D., Boscencu R., Socoteanu R., Ilie M., Constantin C., Manda G., Vieira Ferreira L.F. (2011), Synthesis, Spectral and Cytotoxicity Evaluation of Some Asymmetrical Mesoporphyrinic Compounds with Biomedical Application, in CIIEM 2011 - International Congress of Energy and Environment Engineering and Management, pp.144 - 148. ISBN 9052992441 
Otsu K., Sato K., Ikeda Y., Imai H., Nakagawa Y., Ohba Y., Fujii J. (2005). An abortive apoptotic pathway induced by singlet oxygen is due to the suppression of caspase activation. Biochemical Journal, Vol. 389 Pt 1 (July 1), pp. 197-206, ISSN 0264-6021.

Parsons C., McCoy C.P., Gorman S.P., Jones D.S., Bell S.E.J., Brady C., McGlinchey S.M. (2009). Anti-infective photodynamic biomaterials for the prevention of intraocular lens-associated infectious endophthalmitis. Biomaterials Vol.30 No. 4 (February), pp. 597-602, ISSN 0142-9612, doi: 10.1016/j.biomaterials.2008.10.015

Paszko E., Ehrhardt C., Senge M.O., Kelleher D.P, Reynolds J.V. (2011). Nanodrug applications in photodynamic therapy Photodiagnosis $\mathcal{E}$ Photodynamic Therapy, Vol. 8 No. 1 (March), 14-29, ISSN 1572-1000, doi:10.1016/j.pdpdt.2010.12.001].

Patterson M.S., Mazurek E. (2010). Calculation of Cellular Oxygen Concentration for Photodynamic Therapy In Vitro. In Photodynamic Therapy. Methods and Protocols ,Gomer G.J. (ed.), Methods in Molecular Biology vol. 635, pp. 195-205, Springer New York Dordrecht Heidelberg London, ISBN 978-1-60761-696-2, doi: 10.1007/978-160761-697-9_14.

Pattingre S., Tassa A., Qu X., Garuti R., Liang X.H., Mizushima N., Packer M., Schneider M.D., Levine B. (2005). Bcl-2 Antiapoptotic Proteins Inhibit Beclin 1-dependent Autophagy. Cell Vol. 122 No. 6, pp. 927-939, ISSN 0914-7470, doi: 10.1016/j.cell.2005.07.002

Pavani C., Uchoa A.F., Oliveira C.S., Iamamoto Y, Baptista M.S. (2009). Effect of zinc insertion and hydrophobicity on the membrane interactions and PDT activity of porphyrin photosensitizers. Photochemical \& Photobiological Sciences, Vol. 8 No.2, pp. 233-240, ISSN 1474-905X, doi: 10.1039/B810313E

Petit A., Loupy A., Maillard Ph., Momenteau M. (1992). Microwave Irradiation in Dry Media: A New and Easy Method for Synthesis of Tetrapyrrolic Compounds. Synthetic Communications: An International Journal for Rapid Communication of Synthetic Organic Chemistry, Vol. 22 No. 8, pp. 1137-1142, ISSN 0039-7911, doi: 10.1080/00397919208021097.

Price M., Reiners J.J., Santiago A.M., Kessel D. (2009). Monitoring Singlet Oxygen and Hydroxyl Radical Formation with Fluorescent Probes During Photodynamic Therapy. Photochemistry \& Photobiology Vol. 85 No. 5 (September/October), pp. 1177-1181, ISSN 0031-8655, doi: 10.1111/j.1751-1097.2009.00555.x

Rabbani Z.N., Spasojevic I., Zhang X., Moeller B.J., Haberle S., Vasquez-Vivar J., Dewhirst M.W., Vujaskovic Z., Batinic-Haberle I. (2009). Antiangiogenic action of redoxmodulating $\mathrm{Mn}(\mathrm{III})$ meso-tetrakis(N-ethylpyridinium-2-yl) porphyrin, MnTE-2PyP5+, via suppression of oxidative stress in a mouse model of breast tumor. Free Radical Biology \& Medicine Vol. 47 No.1 (October 1), pp. 992-1004, ISSN 0891-5849, doi: 10.1016/j.freeradbiomed.2009.07.001.

Rai P., Mallidi S., Zheng X., Rahmanzadeh R., Mir Y., Elrington S., Khurshid A., Hasan T. (2010). Development and applications of photo-triggered theranostic agents. Advanced Drug Delivery Reviews, Vol. 62 No. 11 (August 30), pp. 1094-1124, ISSN 0169-409X, doi: 10.1016/j.addr.2010.09.002

Rao P.D., Dhanalekshmi S., Littler B. J., Lindsey J. S. (2000). Rational Syntheses of Porphyrins Bearing up to Four Different Meso Substituents, Journal of Organic Chemistry Vol. 65 No. 22 (September), pp. 7323-7344, DOI: 10.1021/jo000882k 
Rebouças J.S.; DeFreitas-Silva G.; Idemori Y.M., Spasojević I., Benov L., Batinić-Haberle I. (2008a). Impact of electrostatics in redox modulation of oxidative stress by $\mathrm{Mn}$ porphyrins: protection of SOD-deficient Escherichia coli via alternative mechanism where $\mathrm{Mn}$ porphyrin acts as a Mn carrier. Free Radical Biology $\mathcal{E}$ Medicine Vol. 45 No 2 (July 15), pp. 201-210, ISSN 0891-5849, doi: 10.1016/j.freeradbiomed.2008.04.009.

Rebouças J.S., Spasojević I., Tjahjono D.H., Richaud A., Mendez F., Benov L., Batinić-Haberle I. (2008b). Redox modulation of oxidative stress by Mn porphyrin-based therapeutics: the effect of charge distribution. Dalton Transactions, No.9, pp. 12331242, ISSN 1477-9226, doi: 10.1039/B716517J

Rees J.R.E., Lao-Sirieix P., Wong A., Fitzgerald R.C. (2010). Treatment for Barrett's oesophagus. Cochrane Database of Systematic Reviews Issue 1. Art. No.: CD004060. doi: 10.1002/14651858.CD004060.pub2

Renner M.W., Miura M., Easson M.W., Vicente M.G.H. (2006). Recent progress in the syntheses and biological evaluation of boronated porphyrins for boron neutroncapture therapy. Anticancer Agents Medicinal Chemistry Vol. 6 No.2 (October 31), pp. 145-157, ISSN: 1871-5206, doi: 10.1002/chin.200644231

Rosenthal M.A., Kavar B., Uren S., Kaye A.H. (2003). Promising survival in patients with high-grade gliomas following therapy with a novel boronated porphyrin. Journal of Clinical Neuroscience Vol. 10 No. 4 (July), pp. 425-427, ISSN 0967-5868, doi: 10.1016/S0967-5868(03)00062-6.

Rothemund P. (1936). A New Porphyrin Synthesis. The Synthesis of Porphin. Journal of American Chemists Society, vol. 58, No. 4 pp. 625-627, ISSN 0002-7863, doi: 10.1021/ja01295a027.

Rothemund, P. (1939). Porphyrin studies. III. The structure of the porphine ring system Journal of American Chemists Society Vol. 61 No. 10, pp. 2912-2015, ISSN 0002-7863

Salvemini D., Little J., Doyle T., Neumann W. (2011). Roles of reactive oxygen and nitrogen species in pain. Free Radical Biology $\mathcal{E}$ Medicine, ISSN 0891-5849, doi:10.1016/j.freeradbiomed.2011.01.026 (Epub ahead of print).

Salvemini D., Neumann W. (2009). Targeting peroxynitrite driven nitroxidative stress with synzymes: A novel therapeutic approach in chronic pain management. Life Sciences Vol. 86 No. 15-16 (April 10), pp. 604-614, ISSN 0024-3205, doi: 10.1016/j.lfs.2009.06.011

Santos P.F., Reis L.V., Almeida P., Oliveira A.S., Vieira Ferreira L.F., Singlet oxygen generation ability of squarylium cyanine dyes, J.Photochem. Photobiol. A: Chem. 160 (2003) pp. 159-161. ISSN 09380856, doi: 10.1013/j.bmc.2005.03.062

Santos P.F., Reis L.V., Almeida P., Serrano J.P., Oliveira A.S., Vieira Ferreira L.F., Efficiency of singlet oxygen generation of aminosquarylium cyanines, J.Photochem. Photobiol. A: Chem. 163 (2004) pp. 267-269. ISSN 0001-4845, 25 doi: 10.1011/ar0300012

Schneider R.; Schmitt F.; Frochot C.; Fort Y.; Lourette N.; Guillemin F.; Müller J.F.; BarberiHeyob M. (2005). Design, synthesis, and biological evaluation of folic acid targeted tetraphenylporphyrin as novel photosensitizers for selective photodynamic therapy, Bioorganic \& Medicinal Chemistry, Vol 13 No. 8 (April 15), pp. 2799-808,. ISSN 09680896, doi: 10.1016/j.bmc.2005.02.025 
Senge M.O. (2005). Nucleophilic Substitution as a Tool for the Synthesis of Unsymmetrical Porphyrins. Accounts of Chemical Research Vol. 38 No. 9, 733-743, ISSN 0001-4842, doi: $10.1021 / \operatorname{ar} 0500012$

Senge M.O., Shaker Y.M., Pintea M., Ryppa C., Hatscher S.S., Ryan A., Sergeeva Y., (2010). Synthesis of meso-substituted ABCD-type porphyrins by functionalization reactions. European Journal of Organic Chemistry No.2 (January), pp. 237-258, ISSN 1434-193X, doi: 10.1002/ ejoc.200901113

Sessler J.L., Weghorn S.J., Lynch V., Johnson M.R. (1994a). Turcasarin, The Largest Expanded Porphyrin Prepared to Date. Angewandte Chemie International Edition English, vol. 33, pp. 1509-1512, ISSN. 1433-7851

Sessler J.L.; Brucker E.A.; Weghorn S.J.; Kisters M.; Schäfer M., Lex J., Vogel E. (1994b). Corrphycene: A New Porphyrin Isomer. Angewandte Chemie International Edition English, vol. 33, pp. 2308-2312, ISSN. 1433-7851

Sessler J.L., Davis JM, Lynch V. (1998). Synthesis and Characterization of a Stable Smaragdyrin Isomer. Journal of Organic Chemistry Vol. 60 No. 23 (September), pp. 7062-7065, ISSN 1434-193X, doi: 10.1021/jo981019b

Shahbazi-Gahrouei D., Williams M., Rizvi S., Allen B.J. (2001). In vivo studies of Gd-DTPAmonoclonal antibody and Gd-porphyrins: potential magnetic resonance imaging contrast agents for melanoma. Journal of Magnetic Resonance Imaging, Vol.14 No.2 (August), pp. 169-174, ISSN 1053-1807, doi: 10.1002/jmri.1168.

Song R.; Kim Y.S.; Sohn Y.S. (2002). Synthesis and selective tumor targeting properties of water soluble porphyrin-Pt(II) conjugates, Journal Inorganic Biochemistry. Vol. 89 No. 1-2 (April 10) pp.83-88, ISSN 0162- 0134, doi: 10.1016/S0162-0134(01)00413-5.

Sortino S. (2008). Nanostructured molecular films and nanoparticles with photoactivable functionalities. Photochemical \& Photobiological Sciences, Vol. 7, pp. : 911-924, ISSN 1474-905X, doi: 10.1039/B807353H.

Spikes J.D. (1989). Photosensitization. In The Science of Photobiology. Photosensitization, Smith K.S. (Ed.), pp. 79-110. Plenum Press, ISBN 978-0306430596 New York, London.

Tang H.M., Hamblin M.R., Yow C.M. (2007). A comparative in vitro photoinactivation study of clinical isolates of multidrug-resistant pathogens. Journal of Infection and Chemotherapy Vol 13 No.2 (April), pp. 87-91, ISSN 1341-321X, doi: 10.1007/s10156006-0501-8.

van Duijnhoven F.H., Aalbers R.I., Rovers J.P., Terpstra O.T., Kuppen P.J. (2003). The immunological consequences of photodynamic treatment of cancer, a literature review. Immunobiology Vol. 207 No. 2, pp. 105-113, ISSN 0171-2985, doi: 10.1078/0171-2985-00221.

Verma S., Watt G.M., Mai Z., Hasan T. (2007). Strategies for enhanced photodynamic therapy effects Photochemistry \& Photobiology Vol 83 No. 5 (September/October) pp. 996-1005, ISSN 0031-8655, doi: 10.1111/j.1751-1097.2007.00166.x

Vicente M.G.H. (2001). Porphyrin-based sensitizers in the detection and treatment of cancer: recent progress. Current Medicinal Chemistry - Anti-Cancer Agents Vol. 1, No. 2 (August), pp. 175-194, ISSN 1568-0118.

Vicente M.G.H., Wickramasighe A., Nurco D.J., Wang H.W.H., Nawrocky M.M., Makar M.S., Miura M. (2003). Syntheses, toxicity and biodistribution of two 5,15-di[3,5(nido-carboranyl-methyl)phenyl]porphyrin in EMT-6 tumor bearing mice. 
Bioorganic \& Medicinal Chemistry Vol. 11 No. 14 (July 17) pp. 3101-3108, ISSN 09680896, doi: 10.1016/S0968-0896(03)00240-2.

Vicente M.G.H., Sibrian-Vazquez M. (2010). Syntheses of boronated porphyrins and their application in BNCT. In: The Handbook of Porphyrin Science. Vol. 4. pp.: 191-248 Kadish K.M., Smith K.M., Guilard R. (Eds.) World Scientific Publishers ISBN 978981-4280-16-7, Singapore.

Vrouenraets M.B., Visser G.W.M., Snow G.B., van Dongen G.A.M.S. (2003). Basic principles, applications in oncology and improved selectivity of photodynamic therapy Anticancer Research Vol. 23 No. 1B, pp. 505-522, ISSN 0250-7005.

Wainwright M. (2010). Therapeutic applications of near-infrared dyes, Coloration Technology, Vol. 126, Iss. 3, 115-123, ISSN 1478-4408, doi: 10.1111/j.1478-4408.2010.00244.x

Wiehe A., Shaker Y. M., Brandt J.C., Mebs S., Senge M.O. (2005). Lead structures for applications in photodynamic therapy. Part 1: Synthesis and variation of $\mathrm{m}$-THPC (Temoporfin) related amphiphilic $\mathrm{A}_{2} \mathrm{BC}$-type porphyrins, Tetrahedron Vol. 61, No. 23 (June 6), pp. 5535-5564, ISSN 0040-4020, doi: 10.1016/j.tet.2005.03.086

Wilson B.C., Patterson M.S., Lilge L. (1997). Implicit and explicit dosimetry in photodynamic therapy: a New paradigm. Lasers in Medical Science Vol. 12, No.3 (October), pp. 182199, ISSN 0268-8921.

Wilson B.C. (2002). Photodynamic therapy for cancer: Principles. Canadian Journal of Gastroenterology, Vol. 16 No.6, pp. 393-396, ISSN 1352-0504.

Winkelman J.W., Collins G.H. (1987). Neurotoxicity of tetraphenylporphinesulfonate TPPS4 and its relation to photodynamic therapy Photochemistry $\mathcal{E}$ Photobiology, Vol. 46 No. 5 (November), pp. 801-807, ISSN 0031-8655, doi: 10.1111/j.1751-1097.1987.tb04851.x

Witko-Sarsat V., Rieu P., Descamps-Latscha B., Lesavre P., Halbwachs-Mecarelli L. (2000). Neutrophils: molecules, functions and pathophysiological aspects. Laboratory Investigation Vol. 80 No.5 (May), pp 617-653, ISSN 0023-6837.

Xue L.Y., Chiu S.M., Azizuddin K., Joseph S., Oleinick N.L. (2007). The death of human cancer cells following photodynamic therapy: Apoptosis competence is necessary for Bcl-2 protection but not for induction of autophagy. Photochemistry $\mathcal{E}$ Photobiology Vol. 83 No. 5 (Sept-Oct), pp. 1016-1023, ISSN 0031-8655, DOI: 10.1111/j.1751-1097.2007.00159.x

Yu G., Durduran T., Zhou C., Wang H.W., Putt M.E., Saunders H.M., Sehgal C.M., Glatstein E., Yodh A.G., Busch T.M. (2005). Noninvasive monitoring of murine tumor blood flow during and after photodynamic therapy provides early assessment of therapeutic efficacy. Clinical Cancer Research Vol 11 No. 9 (May 1), pp. 3543-3552, ISSN 1078-0432, doi: 10.1158/1078-0432.CCR-04-2582.

Zhang Y., Aslan K., Previte M.J.R., Geddes C.D. (2008). Plasmonic engineering of singlet oxygen generation. Proceedings of the National Academy of Science of the United States of America vol. 105 no. 6 (February 12), pp. 1798-1802, ISSN 0027-8424, doi: 10.1073/pnas.0709501105

Zhu Z, Tang Z., Phillips J.A., Yang R., Wang H., Tan W. (2008). Regulation of Singlet Oxygen Generation Using Single-Walled Carbon Journal of American Chemical Society Vol. 130 No. 33 (August 20), pp. 10856-10857, ISSN 0002-7863, doi: 10.1021/ja802913f 


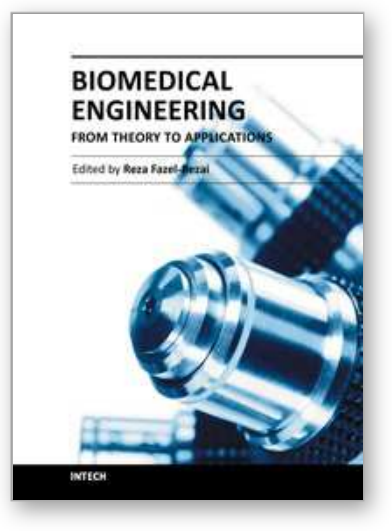

\author{
Biomedical Engineering - From Theory to Applications \\ Edited by Prof. Reza Fazel
}

ISBN 978-953-307-637-9

Hard cover, 486 pages

Publisher InTech

Published online 29, August, 2011

Published in print edition August, 2011

In all different areas in biomedical engineering, the ultimate objectives in research and education are to improve the quality life, reduce the impact of disease on the everyday life of individuals, and provide an appropriate infrastructure to promote and enhance the interaction of biomedical engineering researchers. This book is prepared in two volumes to introduce a recent advances in different areas of biomedical engineering such as biomaterials, cellular engineering, biomedical devices, nanotechnology, and biomechanics. It is hoped that both of the volumes will bring more awareness about the biomedical engineering field and help in completing or establishing new research areas in biomedical engineering.

\title{
How to reference
}

In order to correctly reference this scholarly work, feel free to copy and paste the following:

Radu Socoteanu, Rica Boscencu, Anca Hirtopeanu, Gina Manda, Anabela Sousa Oliveira, Mihaela llie and Luis Filipe Vieira Ferreira (2011). Trends in Interdisciplinary Studies Revealing Porphyrinic Compounds Multivalency Towards Biomedical Application, Biomedical Engineering - From Theory to Applications, Prof. Reza Fazel (Ed.), ISBN: 978-953-307-637-9, InTech, Available from:

http://www.intechopen.com/books/biomedical-engineering-from-theory-to-applications/trends-ininterdisciplinary-studies-revealing-porphyrinic-compounds-multivalency-towards-biomedical-

\section{INTECH}

open science | open minds

\author{
InTech Europe \\ University Campus STeP Ri \\ Slavka Krautzeka 83/A \\ 51000 Rijeka, Croatia \\ Phone: +385 (51) 770447 \\ Fax: +385 (51) 686166 \\ www.intechopen.com
}

\author{
InTech China \\ Unit 405, Office Block, Hotel Equatorial Shanghai \\ No.65, Yan An Road (West), Shanghai, 200040, China \\ 中国上海市延安西路65号上海国际贵都大饭店办公楼 405 单元 \\ Phone: +86-21-62489820 \\ Fax: $+86-21-62489821$
}


(C) 2011 The Author(s). Licensee IntechOpen. This chapter is distributed under the terms of the Creative Commons Attribution-NonCommercialShareAlike-3.0 License, which permits use, distribution and reproduction for non-commercial purposes, provided the original is properly cited and derivative works building on this content are distributed under the same license. 